\title{
CRISE CAPITALISTA, DURAÇÃO DO TRABALHO E GESTÃO EMPRESARIAL
}

\author{
WILSON RAMOS FILHO*
}

\begin{abstract}
RESUMO: Depois de uma brevíssima incursão sobre os modos de regulação estatal sobre a duração do trabalho assalariado e das metamorfoses havidas no modo de gestão das empresas nos últimos quarenta anos, se buscará identificar as principais características da gestão capitalista neofordista, contemporânea ao neoliberalismo, que terminaram por ampliar não apenas a produtividade das empresas como também a sua lucratividade, correlacionando-as com dados comparativos quanto à carga horária semanal em diversos países para, ao final, concluir que mesmo sendo justa, oportuna e factível a redução da carga horária semanal reivindicada pelo movimento sindical, a mesma só virá em decorrência de alteração da correlação de forças na sociedade.

PALAVRAS-CHAVE: Duração do Trabalho; Quarenta Horas; Espíritos do Capitalismo; Crise do Capitalismo.
\end{abstract}

ABSTRACT: After a very brief incursion on the means of state regulation of salary work duration and on the metamorphoses occurred on the manner of company management on the last forty years, we try to identify the main characteristics of the capitalist neofordian management, contemporary to neoliberalism, characteristics which ended up broadening not only company productivity but also their profit. We correlate then with comparative data as to the weekly total work hours of several countries in order to, in the end, conclude that even though fair, opportunist and doable, a reduction of such weekly working hours, which is demanded by the union movement, will only come as a result of change in the correlation of forces in society.

KEYWORDS: Work duration; Forty hours; Spirits of capitalism; Capitalism crisis.

SUMÁRIO: 1. Introdução; 2. Tempo de trabalho e capitalismo: a luta pela regulamentação da duração do trabalho no Brasil; 3. A duração do trabalho e a legitimação do capitalismo; 4. Novas formas de gestão, legitimação do capitalismo e duração do trabalho; 5 . Considerações finais; 6. Bibliografia.

SUMMARY: 1. Introduction; 2. Working hours and capitalism: the fight for the regulation of working hours in Brazil; 3. The work duration and the legitimating of capitalism; 4. New ways of management, the legitimating of capitalism and the work duration; 5. Final considerations, 6. Bibliography.

\footnotetext{
* Doutor em Direito, advogado (www.declatra.adv.br). Professor no mestrado em direito da UNIBRASIL, no Máster Oficial e no Doctorado en Derechos Humanos, interculturalidade y desarrollo, na Universidad Pablo de Olavide, Espanha, e na graduação, mestrado e doutorado na faculdade de direito da UFPR, em Curitiba, nas disciplinas de direito sindical e de direito do trabalho. Atualmente realiza pesquisa em pós-doutorado na École de Hautes Études en Sciences Sociales, em Paris.
} 


\section{INTRODUÇÃO}

A crise econômica, tema até então restrito às publicações econômicas ou da ciência da administração, passa no início de 2009 a aparecer em diversas publicações jurídicas, demonstrando que direito não escapa das condicionantes que lhe são impostas pelo contexto social. No campo do direito do trabalho, do mesmo modo, já se fala na necessidade de um "direito do trabalho de emergência ou de crise” para enfrentar os sobressaltos, cada vez mais frequentes da gestão capitalista (NASCIMENTO, 2009:7).

Nesse contexto, a par de diversas proposições com características liberalizantes aparecem outras, de caráter mais intervencionista, visando o combate ao desemprego, efeito imediato da crise econômica ${ }^{1}$. Entre estas se situa a proposta de redução da carga horária de trabalho, uma vez que a emergência a crise terminou por acelerar a tramitação da proposta de emenda constitucional que trata da redução da jornada de trabalho (PEC 231/95), processo no qual serão ouvidos os setores sociais interessados, dentre os quais os sindicatos de trabalhadores e as organizações empresariais.

As centrais sindicais de trabalhadores ${ }^{2}$, que em movimento unificado desde o início do ano anterior vinham insistindo para a necessidade de redução da carga horária semanal por conta do aumento da produtividade havido nas empresas, estimado em mais de $150 \%$ nos últimos anos, diante da crise ${ }^{3}$, passaram a sustentar haver mais razões agora para a aprovação da medida, acrescida do estabelecimento de limites para a utilização das horas extras.

A Confederação Nacional da Indústria (CNI), entidade que congrega os principais empregadores do País, por outro lado, considera que a crise impediria o atendimento da reivindicação das centrais sindicais obreiras, de diminuição da jornada com preservação dos níveis de salário, por considerar que isso poderia provocar aumento linear de $10 \%$ no custo do trabalho, afetando todas as empresas, independentemente de porte, setor ou região. Segundo seu presidente, deputado Armando Monteiro (PTB/PE), a alternativa para permitir a retomada da geração de postos de trabalho seria a desoneração dos encargos trabalhistas, além do próprio crescimento econômico, não a redução da duração semanal do trabalho. No mesmo sentido é a posição da Federação das Indústrias do Estado do Paraná (FIEP), segundo seu presidente Rodrigo da Rocha Loures também contrária à redução da carga horária semanal, ao argumento de que a interferência estatal poderia gerar desorganização nas negociações coletivas de

\footnotetext{
${ }^{1}$ Segundo a OIT “a atual crise econômica irá gerar 20 milhões de novos desempregados no mundo até o final de 2009, revertendo anos de avanços na área social e agravando a pobreza e desigualdade. O alerta é da Organização Internacional do Trabalho (OIT) que prevê demissões em massa diante da desaceleração das principais economias do mundo, como Estados Unidos, Europa e Japão", conforme veiculado em: http://www.estadao.com.br/economia/not_eco262943,0.htm.

${ }^{2}$ A campanha unitária foi lançada ainda antes do auge da crise, em primeiro de maio de 2008, pelas seis centrais sindicais brasileiras: Central Autônoma dos Trabalhadores (CAT), Confederação Geral dos Trabalhadores (CGT), Central Geral dos Trabalhadores do Brasil (CGTB), Central Única dos Trabalhadores (CUT), Força Sindical (FS) e Social Democracia Sindical (SDS).

${ }^{3}$ Jornal Gazeta do Povo, retrospectiva 2008, publicada em 31 de dezembro: "2008 ficará na história como o ano em que os fundamentos capitalistas foram colocados em xeque. A economia mundial sofreu o maior abalo desde a grande depressão de 1929, e o Brasil não saiu ileso”, conforme http://portal.rpc.com.br/gazetadopovo/ retrospectiva/conteudo.phtml?tl=1\&id=842820\&tit=Crise-no-centro-do-capitalismo.
} 
trabalho, razão pela qual considera que "aumento de salário e diminuição da jornada de trabalho sem redução de salário deve decorrer de aumento de produtividade e serem acordados durante negociação coletiva por empresários e trabalhadores”4.

Por outro lado, o presidente nacional da maior central sindical brasileira (CUT), Artur Henrique, contesta a tese de que a diminuição da jornada diminuiria a competitividade da indústria brasileira, prejudicando as exportações do País argumentando que nem o Fórum Econômico Mundial de Davos considera os baixos salários como fator positivo na hora de medir a competitividade de uma economia nacional, e defende a redução da carga horária semanal, para todos os trabalhadores, por força de lei, sustentando a necessidade de aprovação da emenda constitucional neste sentido ${ }^{5}$.

Não é, como se vê, muito fácil encontrar-se pontos de convergência nesta temática, inclusive porque sua discussão se reveste de forte conteúdo ideológico.

Racionalmente se sabe que o impacto final da redução da duração do trabalho aos níveis praticados pela maioria dos países nos custos do trabalho são infinitamente menores do que impacto, simbólico, que tal regulação estatal provoca no conjunto de representações ideológicas do empresariado. Por outro lado, também se sabe racionalmente - que tal medida teria impacto nos níveis de emprego, embora talvez não tão grande como apregoado por parte de seus defensores.

Neste ano se comemoram os noventa anos desde a aprovação da primeira convenção internacional sobre a duração do trabalho. Do mesmo modo, passados quase três quartos de século desde a aprovação da Convenção da OIT n. 47, de 1935, que aconselha a adoção da semana laboral de quarenta horas, na América Latina, o Brasil incluído, ainda se resiste às suas diretivas, embora mais de $40 \%$ dos países no mundo já adotem a semana de quarenta horas, ou menos ${ }^{6}$, independentemente do grau de industrialização ou de desenvolvimento econômico de suas economias.

De fato, segundo demonstram estudos da OIT reproduzidos mais adiante neste artigo, dentre os industrializados, quase $60 \%$ dos países adotam a semana de quarenta horas (10\% deles, semanas de 35 a 39 horas semanais), mas o que pode surpreender é que efetivamente a distribuição dos países por regiões geográficas é mais significativa para o estabelecimento de limites mínimos do que o grau de industrialização ou de desenvolvimento. Como se verá, na África e na Ásia há mais países que consagram em suas legislações a semana de quarenta horas do que nas Américas.

O artigo foi estruturado em três seções além desta introdução e das considerações finais. No próximo tópico será historiada a luta pela regulação do trabalho no Brasil. Nos dois tópicos seguintes serão analisados a regulação estatal e os principais

\footnotetext{
${ }^{4}$ Conforme informativo do Sindicato das Indústrias do Vestuário do Paraná, encontrável no sitio abaixo, consultado em 15.02.2009: http://www.sindvestmaringa.com.br/?action=ver_noticia\&read=101.

${ }^{5}$ Conforme noticiado em 10.02.2009: http://www2.camara.gov.br/internet/homeagencia/materias.html? $\mathrm{pk}=130925$.

${ }^{6}$ Em números redondos, em amostra de mais de cem países, pouco mais de $40 \%$ dos países adota cargas horárias semanais inferiores a 40 horas, 20\% dos países adota semanas laborais entre 41 e 45 horas e outros $20 \%$ entre 45 e 48 horas semanais. Os restantes quase $10 \%$ dos países não adotam limite legal algum, preferindo a sua fixação em contratos coletivos.
} 
elementos caracterizadores da gestão empresarial na contemporaneidade. Ao final, estabelecidas as premissas a partir das quais a discussão sobre a redução da carga horária semanal haverá de se dar, se considerará que - possível e aconselhável - a redução da carga horária em nosso não virá como decorrência de processos de racionalização ou do progresso econômico do país, mas de correlação de forças na sociedade, entre as classes sociais envolvidas.

2. TEMPO DE TRABALHO E CAPITALISMO: A LUTA PELA REGULAMENTAÇÃO DA DURAÇÃO DO TRABALHO NO BRASIL

Para que o capitalismo pudesse se converter em modo de produção hegemônico, foi necessária a criação de sistemas de controle do tempo e, mais ainda, das parcelas de tempo durante as quais os trabalhadores vendiam suas forças de trabalho mediante remuneração, ensejando o surgimento da disciplina científica dos tempos de trabalho.

A produtividade passa a ser medida pela quantidade de produtos fabricados ao longo de determinado período. Neste sentido, para quem compra a força de trabalho, a produtividade aparece associada às longas jornadas, gerando resistência na classe que vive da venda da força do trabalho. Esta tensão entre quantidade de horas prestadas como contrapartida pela quantidade de salário pago é inerente ao modo de produção capitalista ${ }^{7}$.

Como resultado desta tensão, inerente às relações capitalistas de produção, a duração do trabalho vem se caracterizando por uma tendência à sua redução, em termos anuais, tendo sido reduzida das 4500 horas prestadas em média ${ }^{8}$ em meados do século XIX às atuais 2240 horas no Brasil ou 1800 ou 1900 horas anuais em vários países desenvolvidos (MEDA, 2001:13).

A fixação por lei daquela que deveria ser considerada como “jornada normal” de trabalho para conter os excessos nas jornadas impostas pelos empregadores, que começa pela regulação do trabalho de crianças e adolescentes ${ }^{9}$, só mais tarde alcança os trabalhadores maiores de dezoito anos.

\footnotetext{
${ }^{7}$ A observação não é nova : " la création d'une journée de travail normale est par conséquent le résultat d'une guerre civil longue, opiniâtre e plus ou moins dissimulée entre la classe capitaliste et la classe ouvrière" (MARX, Le capital: 381)

${ }^{8}$ Na França, antes da Revolução Francesa as corporações proscreviam o trabalho assalariado em várias épocas durante o ano. A Lei Chapelier e a Lei Allarde, votadas ainda no calor revolucionário, em 1791, ao suprimirem as corporações de ofício (consideradas esteios do modo de produção feudal e das relações de trabalho a ele inerentes) permitiram às classes emergentes como dominantes, não apenas universalizar 0 regime do salariado (CASTEL, 1998), mas acima de tudo, propiciou aos empregadores fixar livremente as jornadas de trabalho. O desenvolvimento capitalista sem regulação estatal ou social fez com que o número de horas anuais aumentasse consideravelmente até chegar a 4500 horas em comparação com as menos de 2000 horas anuais de antes da chegada da burguesia ao poder. Tal observação é importante para deixar claro que, pelo menos para a classe trabalhadora, a revolução francesa (que editou a primeira Declaração dos Direitos do Homem) não representou avanços no que respeita à carga horária ou às condições de trabalho.

${ }^{9}$ Na França, uma espécie de Inspeção do Trabalho foi criada para fazer cumprir a lei de 1841 que limitava a 8 horas por dia o trabalho de crianças de oito a doze anos e, mais tarde, outra lei, de 1893, que limitava a jornada de trabalhadores homens a dez horas. Mas não foi só na França que, no transcurso deste primeiro século de desenvolvimento do modo de produção capitalista, fase que se denomina como liberal em homenagem à ideologia hegemônica à época, que as jornadas chegaram a níveis insuportáveis. Na Inglaterra, embora existissem leis disciplinando as jornadas de trabalho desde o início do século a delimitação da jornada dos menores em dez horas só se revela em 1848 no bojo de muitas lutas e de criação da Inspeção do trabalho.
} 
Nos EUA, a primeira consequência do final da guerra civil e da abolição legal da escravatura foi a intensificação da luta pelas oito horas, conforme constava já das reivindicações do Congresso Geral dos Trabalhadores de Baltimore, de 1866. Na Europa, na mesma época ocorre o Congresso da Internacional com idêntica postulação. Contudo, se nos EUA a jornada de oito horas somente foi instituída já em 1890 (depois da morte de vários trabalhadores nos incidentes que eternizaram o dia primeiro de maio como “dia internacional do trabalhador”, exceto naquele país, obviamente), na Europa e no resto do mundo a fixação da duração do trabalho na legislação tardará um pouco mais, pois se vivia o auge do liberalismo.

Dada a hegemonia do ideário liberal, não é de se estranhar que o Direito se abstivesse de regular as relações de trabalho. Com base na noção de contrato ${ }^{10}$ em que, por ajuste de vontades livremente ${ }^{11}$ manifestadas por sujeitos iguais perante a lei (que se encontravam no mercado para intercambiar coisas de valor equivalente), omitia-se a apropriação da mais-valia presente nas relações de trabalho e a desigualdade ínsita que as caracteriza ${ }^{12}$.

Do mesmo modo que nos demais países, também no Brasil as jornadas de trabalho durante todo o século XIX e início do século XX foram bastante elásticas, gerando conflitos e debates sobre a necessidade de sua normatização como condição para o funcionamento do nascente capitalismo.

Logo depois da abolição da escravatura (como relação de trabalho legalizada pelo Direito e pelo Estado Brasileiro) continuou a ser frequente a prestação de jornadas superiores a doze horas de trabalho, eis que o horário de trabalho geralmente coincidia com as horas em que houvesse luz natural, inclusive para as crianças e adolescentes empregados, tanto no campo, quanto nas cidades.

Como ocorrera na Europa depois de muitas lutas sociais ${ }^{13}$, também no Brasil

Apesar de a Alemanha haver ingressado no século XX basicamente feudal já em 1893 foi publicada lei que proibia o trabalho de menores de nove anos e restringia a dez horas o jornada diária para o menores de dezesseis anos (CAHUC, ZYLBERBERG, 2005:59).

${ }^{10}$ Veja-se a respeito, o que dizia MARX ainda em meados do século XIX: "Le contrat par lequel il vendait ça force du travail semblait résulter d'un accord entre deux volontés libres, celle du vendeur et celle du acheteur. L'affaire une fois conclue, il se découvre qu'il n'était point un 'agent libre'; que le temps pour lequel il lui est permis de vendre ça force de travail est le temps pour lequel il est forcé a la vendre; et qu'en réalité le vampire que le suce ne le lâche point 'tant qu'il lui reste un muscle, un nerf, une goutte de sang à exploiter" (MARX, Le capital:385).

${ }^{11}$ Mediante seu consentimento voluntário, o trabalhador submete-se ao empregador sem coerção, utilizando sua razão autônoma para tanto. O sistema liberal exige que as situações de subordinação apareçam como relações de colaboração entre seres livres e iguais; necessita que "um ato de submissão apresente-se sob a máscara de um contrato": "la creación de derecho de forma no impuesta, resultado del concurso de voluntades libres, y que subraya la 'horizontalidad de la producción del derecho', que confunde en una misma persona legislador y sujeto” (BAYLOS, 1991:20).

12 "Na realidade, o trabalhador que celebra o contrato aceita condições pré-fixadas pela parte economicamente mais forte. E o individualismo que em nome desta ficção de igualdade entre as partes, proibia a coligação, a associação e as greves dos trabalhadores, ignorava a solidariedade existente entre eles, como sujeitos econômicos concretos que nada têm a ver com os mitificados sujeitos de direito. $\mathrm{O}$ direito liberal do trabalho assalariado, de forma muito clara, vem evidenciar o seu caráter objetivo de instrumento de domínio da burguesia ascendente sobre a classe dos assalariados” (MOURA, 1984:39).

13 "Il fallut une longue lutte sociale entre les classes avant qu'ils fussent formulés, reconnus officiellement et promulgués au nom de l'Etat " (MARX, Le Capital:362). 
logo após a proclamação da República, já em 1891, foi instituído mecanismo, por decreto, que previa Inspeção por parte do Estado para garantir o cumprimento da norma que limitava nove horas a jornada de trabalho dos meninos de 14 e 15 anos (as crianças de 12 a 14 tinham o teto de sete horas diárias o labor). Todos os demais trabalhadores, a partir dos 16 anos, cumpriam jornadas superiores, geralmente de doze horas diárias, fixadas livremente, sem qualquer limitação, guardando coerência com o Estado Liberal, fundado no contrato e na autonomia da vontade.

No caso brasileiro a resistência operária adquire relevância histórica somente no início do século XX quando ainda em 1907 deflagrou-se aquela que ficou conhecida como "a greve pelas oito horas de trabalho", em diversas cidades do sudeste brasileiro. Dessa época data o livro precursor do direito do trabalho no Brasil, de autoria de Evaristo de Moraes, intitulado “Apontamentos de Direito Operário”, que já percebia que "por toda parte, o industrialismo moderno paga, pelo menor preço possível, a maior quantidade de trabalho que pode obter de uma criatura humana. Esforço máximo mínima remuneração!” (MORAES, 1998:11).

A primeira tentativa de regulação estatal da duração do trabalho, em 1911, de autoria dos deputados Figueiredo Rocha e Rogério Miranda, foi considerada tão avançada aos olhos do empresariado que o projeto que fixava o conceito de jornada normal de trabalho foi considerado anárquico, subversivo e imoral, não chegando nem a ser apreciado formalmente. Dois outros projetos, um de 1915, do deputado Mário Hermes e outro, de 1917, do Deputado Maurício Lacerda, que pretendiam fixar em doze horas o tempo máximo e em oito o horário de trabalho normal, também não chegaram a ser transformados em lei, em decorrência da forte resistência empresarial (DAL-ROSSO, 1996:235).

As primeiras regulamentações heterônomas do trabalho subordinado entre nós vêm somente em consequência das greves de 1917 (e ainda assim em âmbito restrito, provincial) e, pouco depois, da adesão brasileira à primeira Convenção da OIT.

Para os efeitos aqui pretendidos, no curto espaço de um artigo, importa registrar que, em todo esse período que poderia ser considerado como a pré-história do direito do trabalho brasileiro, o debate central por força da radical oposição do empresariado brasileiro $^{14}$, não se dava sobre o número de horas a serem consideradas normais em uma jornada de trabalho, mas sobre a própria possibilidade e a oportunidade de a matéria ser tratada pelo Estado, por via legislativa ${ }^{15}$. O caráter ideológico da postura

\footnotetext{
${ }^{14}$ A oposição dos industriais à legislação de proteção ao trabalhador é um tema clássico da historiografia brasileira. Esse segmento empresarial estava imerso no liberalismo ortodoxo da Primeira República, que não previa a intervenção do Estado na economia, sobretudo em questões relacionadas ao mundo do trabalho. A Constituição de 1891, no seu artigo 72, § 24, determina que "é garantido o livre exercício de qualquer profissão moral, intelectual e industrial”. Isso implica em dizer que a livre-negociação entre as partes envolvidas presidiria a relação capital-trabalho. Portanto, a primeira carta magna do Brasil republicano enquadrava o problema no âmbito do liberalismo ortodoxo. O Código Civil confirmou a postura adotada pela Constituição, ao enquadrar os contratos de trabalho na concepção do contratualismo individualista (SANTANA, 2008).

${ }^{15}$ Em sua extensa e detalhada pesquisa sobre os debates legislativos no período de 1906 a 1932, sobre a duração do trabalho, Josué PEREIRA DA SILVA nos traz importantes trechos de debates parlamentares para demonstrar que os deputados que compunham a maioria resistiam à limitação da jornada na lei por
} 
empresarial fica claro também no episódio da aprovação da primeira legislação de âmbito nacional com características intervencionistas, qual seja o Código de Menores, de 1927 que limitava em seis horas diárias a jornada de trabalho das crianças e adolescentes, que por sua importância histórica merece relato, ainda que sucinto.

O estabelecimento de limites para a duração do trabalho para as crianças e adolescentes deixou o empresariado brasileiro indignado, ferido em seus princípios liberais, ameaçado em seus interesses econômicos. Mesmo tendo sido aprovado ao cabo de intenso debate social, o novo Código de Menores ${ }^{16}$ continuou a suscitar resistência por parte do patronato $^{17}$ quanto à sua eficácia, eis que o empresariado resistia à efetividade da regra nele contida que estabelecia o direito aos adolescentes com menos de 18 anos à jornada máxima de seis horas, com uma hora de intervalo.

Seguindo a tradição liberal os empresários passaram a pressionar o Judiciário “recomendando” aos juízes de menores que deixassem de aplicar aquela parte do Código e que apenas "acompanhassem o trabalho dos pequenos colaboradores da indústria". Tal "recomendação" chegou a ser acatada por alguns magistrados, provisoriamente, "enquanto o Congresso estivesse estudando a remodelação do Código de Menores”. Todavia, em 1929 assumiu como Juiz de Menores do Distrito Federal José Cândido de Albuquerque Mello Mattos, que havia sido um dos redatores do projeto que deu origem ao Código que tanto incomodava ao patronato. Resolvendo colocar em prática a lei que havia ajudado a elaborar, provocou imediata reação dos industriais. Do mesmo modo como haviam feito em relação aos magistrados anteriores, as entidades patronais peticionaram solicitando a suspensão da eficácia daquele dispositivo enquanto o congresso procedia a uma rediscussão a respeito da jornada de trabalho dos menores. O pleito foi indeferido pelo Juiz Mello Mattos que, em seu despacho classificou a demanda dos empresários de "ilegal, injurídica, injusta, desumana e impatriótica" adendando que "cabia, pois ao Estado intervir para que a vida desses menores fosse 'poupada a todo transe’: o Estado 'deve intervir com sua proteção aos menores nas ruas e nas oficinas, na exploração pelos pais e pelos patrões, na fiscalização dos divertimentos comercializados, no uso de narcóticos, na disseminação dos vícios etc" (PEREIRA DA SILVA, 1996:190 e 192).

considerá-la um atentado à liberdade, não dos empregadores, mas dos próprios trabalhadores que se veriam impedidos de dispor de suas forças de trabalho como melhor lhes aprouvesse. Ou seja, mesmo considerando que existiam, minoritários defensores do intervencionismo estatal, majoritariamente os parlamentares liberais opunham-se à regulamentação pela via legislativa, por razões ideológicas. De toda sorte, conforme aponta o autor, apesar de toda a discussão em torno da fixação da jornada (em dez ou em oito horas diárias) acabou restando infrutífera eis que nenhum dos projetos em discussão terminou sendo aprovado pelo Congresso, antes do final da primeira guerra e do Tratado de Versailles (PEREIRA DA SILVA, 1996:167).

${ }^{16}$ Decreto Legislativo ${ }^{\circ} 5.083$, de 01 de dezembro de 1926.

${ }^{17}$ Inconformados com a intervenção do Estado, os empresários argumentavam que a nova lei criava disparidade entre os empregados e que isso conturbaria a racionalidade do processo produtivo. Haveria, segundo eles, uma impossibilidade de se adotar nas fábricas uma jornada de trabalho de seis horas para os adolescentes até 18 anos, e de oito para os adultos. Para superá-la, ameaçavam, a saída seria contratar apenas adultos, em prejuízo dos próprios menores que a lei pretendia proteger. Todavia, na verdade tratava-se meramente de custos de produção, pois o operário adulto não aceitaria ser contratado pelo salário então pago aos menores para desempenhar aquelas funções: "para os patrões os trabalhadores menores representavam antes de tudo uma força de trabalho barata e de manipulação mais fácil que os adultos” (PEREIRA DA SILVA, 1996:183). 
O Estado já não era mais o mesmo, o direito já não era o mesmo. O intervencionismo estatal começava a se tornar hegemônico, como ficará evidente no ano seguinte com a chegada de Getúlio Vargas ao poder (em 1930), e com ele, da ideologia intervencionista, que entre nós revestiu-se de características muito peculiares.

No que tange à legislação ordinária, nos anos de 1932 até 1934, materializando tal ideologia, diversos Decretos foram publicados com o objetivo de regular as jornadas das mais variadas categorias profissionais ${ }^{18}$, limitando-as em no máximo oito horas, apesar de o Brasil ter aderido às convenções internacionais da OIT sobre limites à jornada de trabalho.

De todo modo, embora os empresários ligados à Federação das Indústrias do Estado de São Paulo (FIESP) tenham exercido pressão em sentido contrário ${ }^{19}$, a Constituição de 1934 consagrou a duração da jornada em oito horas por dia e quarenta e oito horas semanais, condição mantida na Constituição de 1937.

A legislação esparsa só foi sistematizada pelo Decreto-lei $\mathrm{n}^{\circ} 2.308$, de 13 de junho de 1940, sucedido pela CLT, de $1^{\circ}$ de maio de 1943, consolidando entre nós a carga horária semanal de quarenta e oito horas, como na maioria dos países de então, situação que se manteve até 1988, quando, não sem nova forte e renhida resistência dos empregadores (com argumentos muito parecidos com aqueles utilizados por seus homólogos no início do século), foi inscrita na Constituição brasileira a semana de quarenta e quatro horas de trabalho.

\section{A DURAÇÃo DO TRABALHO E A LEGITIMAÇÃO DO CAPITALISMO}

A maneira de o capitalismo obter adesão dos trabalhadores e do conjunto da sociedade aos seus interesses, legitimando o modelo de sociedade que propõe, veio se alterando ao longo do período histórico tratado no tópico anterior, razão pela qual resta insuficiente analisar apenas as profundas alterações sentidas pelo direito moderno para regular as condições de funcionamento da sociedade no mesmo período, inclusive quanto à regulação do trabalho prestado em condições de subordinação. Para uma compreensão mais ampla se faz necessária a análise dos sistemas de justificação do modo de produção, que também sofreu metamorfoses nesses duzentos últimos anos.

A primeira metamorfose significativa neste processo foi a que possibilitou a diferenciação ideológica em face da visão de mundo pré-capitalista. Em sua obra clássica Max WEBER demonstrou que um “novo espírito”, capitalista, possibilitou aos protestantes do final do século XIX enriquecer rapidamente usando uma nova

\footnotetext{
${ }^{18}$ No início da Era Vargas, período de várias alterações na legislação trabalhista, disciplinou-se a duração da jornada de trabalho de diversas categorias, dentre as quais se destaca: no comércio (decreto 21.186 de 1932), na indústria (Decreto $n^{\circ} 21.364$ de 1932), nas farmácias (Decreto $n^{\circ} 23.084$, de 1933), nas casas de diversão (Decreto $n^{\circ} 23.152$, de 1933), nas casas de penhores (Decreto $n^{\circ} 23.316$, de 1933), nos transportes terrestres (Decreto $n^{\circ}$ 23.766, de 1934) e nos hotéis (Decreto $n^{\circ} 24.696$, de 1934), sempre, portanto, por legislações específicas por categorias profissionais (NASCIMENTO, 2008:72).

${ }^{19}$ No início da década de 30 “.... F FIESP (Federação das Indústrias do Estado de São Paulo) se manifestava a respeito do assunto: 'achamos um erro a imposição do horário de oito horas para todos os ramos industriais, pois alguns exigem horário menor e outros maior, uma vez que as indústrias divergem profundamente umas das outras’...” (PEREIRA DA SILVA, 1996:175)
} 
racionalidade e determinação para ganhar dinheiro e acumular recursos. Suas análises demonstram também que o espírito do capitalismo foi muito além do mero acúmulo monetário. Exigiu principalmente que houvesse na sociedade uma predisposição para os negócios, com indivíduos disciplinados, austeros, econômicos. Para que o capitalismo se tornasse hegemônico foi necessária a existência de "trabalhadores conscientizados" a produzir cada vez mais, visando "melhorar de vida”, ao contrário do que caracterizava o modo de produção anterior e da ideologia religiosa que lhe dava sustentação, o catolicismo. Esse novo ethos, essa nova posição frente ao mundo, é que teria possibilitado ao capitalismo tornar-se modo de produção dominante, em contraposição à visão anterior que priorizava o trabalho apenas como meio de sobrevivência. Para que o capitalismo se transformasse em modo de produção dominante, segundo Max WEBER teria sido necessário que os trabalhadores fossem convencidos de que estas, e não outras, seriam as melhores bases para sociedade que se estava construindo.

$\mathrm{Na}$ nova ética da prosperidade, em substituição àquela característica das sociedades anteriores, se faz necessária a subserviência dos trabalhadores ao regime do salariado. Para desviar a atenção dos trabalhadores das condições objetivas decorrentes das relações capitalistas de produção se fez necessário construir-se um conjunto de representações que "conscientizasse" os trabalhadores de que esta seria a melhor sociedade, como um absoluto, uma vocação, e para tanto a educação exerce papel relevante. Essa educação, econômica e religiosa a um só tempo, permitiu a constituição do "espírito do capitalismo", motivando as pessoas a quererem sempre ganhar mais, produzir mais, em um processo que se auto-legitimava (WEBER, 2004).

A apertada síntese histórica do processo de fixação de uma carga horária semanal de trabalho ordinária, realizada no item anterior, serviu para demonstrar que nesta fase inicial do primeiro espírito do capitalismo, tanto o empresariado quanto os trabalhadores ofereceram resistência à implantação do capitalismo no Brasil, mas por motivos contrários: os trabalhadores lutando por cargas horárias menores e o empresariado resistindo a que se estabelecessem limites para a duração diária no trabalho subordinado.

A adesão do empresariado brasileiro ao sistema de legitimação capitalista, em substituição à pura e dura correlação de forças que caracterizou as primeiras décadas do século XX, vem apenas na ambiência histórica trazida pelo Estado Novo. A partir daí, com o empresariado passa a compreender a nova funcionalidade do Estado e do Direito para a defesa de seus interesses no modo de produção (RAMOS FILHO, 1999), consolidando processos de legitimação deste primeiro espírito do capitalismo e passando a consentir a regulação estatal ${ }^{20}$, exigindo como contrapartida a consolidação do poder patronal, pela via da subordinação.

${ }^{20}$ Tomando como referência o período que vai de 1889 até 1945, conforme já observado, é possível distinguir três fases distintas no comportamento dos industriais referentes à legislação do trabalho: (i) a primeira fase é marcada por uma postura de extremado liberalismo (tipo fordista), hostil à formulação/aplicação de leis sociais; vai de 1889 até 1932, considerando apenas o momento republicano; (ii) a segunda fase é marcada pela “incorporação consentida da legislação por parte dos empresários”. Trata-se de uma posição intermediária. Ainda assim, os conflitos com o Estado prosseguem especialmente em questões de aplicações da lei; (iii) na última fase, ocorre uma identificação entre o empresariado com o direito social; a estrutura corporativa sindical se constitui no projeto consensual das elites e classes dominantes. Cronologicamente essa seria a fase do Estado Novo (SANTANA, 2008). 
Neste sentido se pode afirmar que a ditadura Vargas, de 1930 a 1945 foi o período necessário para que o empresariado brasileiro se apercebesse da ambivalência peculiar ao direito do trabalho: ao assegurar direitos aos empregados, consolida e legitima o poder empresarial e o próprio sistema capitalista.

Este sistema, fundado em peculiar relação entre capital e trabalho, sempre necessitou de elementos justificadores que induzissem à percepção de que este sistema era melhor do que a alternativa então existente. Apresentando-se como portador de perspectivas sedutoras e excitantes (potencializando valores como desempenho individual, empreendedorismo, audácia, liberdade, pluralismo, entre outros) e oferecendo, ao mesmo tempo, garantias de segurança e argumentos morais para que seguisse existindo, justificando-se. O papel desempenhado pelo Direito do Trabalho (e pela Justiça do Trabalho) nesse sistema de legitimação resulta evidente, inclusive em nosso país.

No Brasil, foi a partir da consolidação das leis trabalhistas, em 1943, que esse ramo do direito foi dotado de organicidade e institucionalidade maiores, servindo como elemento na amálgama social então construída no sentido de lograr adesão das pessoas ao modo de vida que propunha. O sistema capitalista, fundado na exploração do trabalho, precisava de elementos justificadores que induzissem à percepção de que este sistema era melhor do que a alternativa então existente, precisava, portanto apresentar perspectivas sedutoras e excitantes (potencialização de valores como desempenho individual, empreendedorismo, audácia, entre outros) e que oferecesse, ao mesmo tempo, garantias de segurança e argumentos morais para que seguisse existindo, justificando-se, sendo óbvio o papel desempenhado pelo Direito do Trabalho (e pela Justiça do Trabalho) nesse sistema de legitimação ${ }^{21}$.

Do mesmo modo que o Estado e o Direito sofreram importantes metamorfoses no transcurso do último século em decorrência de relações entre classes sociais também cambiantes, o sistema de legitimação inerente ao modo de produção capitalista também mudou, principalmente depois de desaparecido o modelo alternativo, representado pelos socialismos reais.

Aquele sistema de garantias que permitiu a regulação da jornada de oito horas e da carga horária semanal em quarenta e oito horas logo no período entre guerras se justificava não apenas pela forte pressão sindical da época, mas muito mais pelo temor das elites empresariais e políticas, principalmente na Europa ocidental, de que o ideário comunista e socialista posto em prática na Rússia pudesse por em risco a continuidade do modo de produção capitalista. Neste sentido é que se diz que o intervencionismo estatal e sua expressão política (a social-democracia) teriam “cedido os anéis para não ceder os dedos”.

Do mesmo modo, o crescimento territorial da União Soviética e de sua importância estratégica política no planeta gerou além da "guerra-fria” o desenvolvimento do

21 “El espíritu del capitalismo debe responder a una exigencia de autojustificación, sobre todo para poder resistir a la crítica anticapitalista, lo que implica un recurso a convenciones de validez universal en cuanto o que es justo e injusto [...] El espíritu del capitalismo proporciona, al mismo tiempo, una justificación al capitalismo (que se opone a los cuestionamientos que pretenden ser radicales) y un punto de apoyo crítico, que permite denunciar la separación entre las formas concretas de acumulación y las concepciones normativas del orden social” (BOLTANSKY, CHIAPELLO, 2002:68) 
intervencionismo estatal no ocidente, com ampliação progressiva dos direitos sociais, como forma de contraposição ideológica ao projeto alternativo, anticapitalista.

Com a descolonização que caracterizou os anos 50 e 60, decorrentes de movimentos de libertação nacional principalmente na África e na Ásia, alguns dos quais fortemente influenciados pelos ideais socialistas, e com a crítica social e cultural endereçada ao capitalismo se viu forçado a reforçar seus mecanismos de justificação. Tais críticas ao capitalismo adquirem grande visibilidade nos países ibero-americanos (motivando golpes contra-revolucionários pelos exércitos apoiados pelos EUA a partir de meados da década de 60 em vários países), na Europa (os movimentos de maio de 1968 sintetizam de algum modo a que se quer referir), e nos EUA (movimentos pacifistas em face das intervenções militares no sudeste asiático, nos anos seguintes).

Fez-se necessário, enfim, louvar as vantagens do sistema capitalista em face do sistema alternativo, buscando demonstrar que era possível atender-se aos direitos sociais sem prejuízo dos direitos civis e políticos. E um dos elementos utilizados pelo modo de produção para se reciclar e para fortalecer seus mecanismos de legitimação (ao lado de outros, como saúde pública, educação pública, regimes de previdência social e de aposentadorias) foi sem dúvida a redução da carga horária.

$\mathrm{Na}$ fase final do que pode ser considerado o primeiro espírito do capitalismo, mesmo na Europa, os limites semanais para a duração do trabalho subordinado ainda eram bastante altos. Estudos demonstram que em 1967 a maioria dos países, incluídos os mais desenvolvidos, ainda se situava na faixa que praticava entre quarenta e uma e quarenta e seis horas semanais de trabalho, segundo a disciplina legal estabelecida e que nenhuma legislação nacional previa carga horária inferior a quarenta horas semanais (OIT, 1967):

\begin{tabular}{|c|c|c|c|}
\hline $\begin{array}{c}1967 \\
\text { (ano base) }\end{array}$ & 40 horas & 41-46 horas & 48 horas \\
\hline África & $\begin{array}{c}\text { Argelia, Camarões, } \\
\text { Chad, Costa do Marfim, } \\
\text { Mali, Mauritânia, } \\
\text { Níger, Senegal } \\
\end{array}$ & & $\begin{array}{l}\text { Moçambique, Tunísia, } \\
\text { Congo, Marrocos }\end{array}$ \\
\hline $\begin{array}{c}\text { Ásia e } \\
\text { Oceania }\end{array}$ & Nova Zelandia & Singapura & $\begin{array}{c}\text { China, Japão, Filipinas, } \\
\text { Tailândia } \\
\end{array}$ \\
\hline Europa & Finlândia, França & $\begin{array}{l}\text { Bélgica, Luxemburgo, } \\
\text { Noruega, Suécia, Suiça. }\end{array}$ & $\begin{array}{c}\text { Áustria, Alemanha, } \\
\text { Irlanda, Itália, Holanda, } \\
\text { Portugal, Espanha }\end{array}$ \\
\hline Américas & Estados Unidos, Canadá & $\begin{array}{l}\text { Guatemala, Venezuela } \\
\text { (comércio e escritórios), } \\
\text { Uruguai (comércio) }\end{array}$ & $\begin{array}{l}\text { Brasil, Peru, Argentina, } \\
\text { Bolívia, Colombia, } \\
\text { Costa Rica, México, } \\
\text { Nicarágua, Panamá, } \\
\text { Uruguai (indústria), } \\
\text { Venezuela (indústria) }\end{array}$ \\
\hline
\end{tabular}

DIREITOS FundAMENTAIS E J JUSTIÇA N' 6 - JAN./MAR. 2009 
Naquele contexto acima lembrado, o ideário de esquerda ganha adeptos e os movimentos sociais e sindicais se fortalecem, na maioria dos países industrializados, tornando possível vislumbrar-se mudança significativa no espírito do capitalismo a partir do final da década de 60 e no início dos anos 70, principalmente depois da crise capitalista de então, conhecida como "choque do petróleo". Tal mudança veio no sentido de se construir um novo sistema de justificação que resistisse melhor à crítica anticapitalista crescente não apenas em todos os países de capitalismo central, configurando o aludido "segundo espírito do capitalismo”, nos países democráticos.

Verdadeiramente os dois modelos, seja o capitalismo de mercado, seja o do socialismo então implantado (que na URSS de então atingira sua conformação mais característica), estavam apoiados no conceito de organização. Segundo a proposta teórica desenvolvida por Jacques BIDET e Gérard DUMÉNIL, os métodos de gestão, fundados no conceito de organização possibilitaram a emergência tanto do socialismo real (pelo qual uma casta de burocratas ocupa o aparelho de Estado para desenvolver políticas distributivistas, ainda que a custa dos direitos civis e políticos) quanto também de um capitalismo organizado (mais resistente às críticas que lhe endereçavam os defensores do sistema concorrente no sentido de que este sistema não asseguraria tanto quanto o outro, os direitos econômicos e sociais), em processo por eles denominado como "révolution managériale” (BIDET; DUMÉNIL, 2007:70).

A experiência soviética, na qual um grupo de burocratas (a nomenklatura), constituído em torno de uma "nova classe dominante", segundo a crítica corrente à época, que exerce o poder de forma pouco democrática na gestão das relações de produção é de todos conhecida. Esse modelo, que era acima de tudo um modelo "gerencial”, segundo a hipótese dos autores acima citados, não resistiu à crítica do modelo alternativo, no final dos anos oitenta, mas no fim dos anos sessenta ainda era dotado de grande força simbólica, decorrente dos resultados distributivistas que possibilitava alcançar.

A experiência ocidental, do modo de produção capitalista, de modo similar ao ocorrido no sistema concorrente, também permitiu o surgimento de uma "nova classe" dirigente que os autores citados denominam como capito-cadrisme ${ }^{22}$ no sentido da governança que os executivos profissionais passam a exercer nas empresas e no próprio desenvolvimento e reciclagem do modo de produção capitalista.

Esse segundo espírito do capitalismo, baseado na figura dos administradores profissionais, dos executivos, no Brasil adquire contornos mais definidos a partir do final da ditadura militar. Um dos temas mais característicos dessa "forma de gestão", nova à época, centra-se na crítica ao nepotismo (sucessão empresarial dentro do que se convencionou chamar de administração familiar) com a hiper-valorização dos executivos profissionalizados, com as defesas de novas formas de gestão que comprometam mais os empregados com o futuro do modo de produção capitalista.

\footnotetext{
22 “'A cet égard, il paraît plus pertinent d'utiliser le terme 'encadrement' plutôt que celui inhérente à tout rapport de classe, et possède l'avantage d'être construit autour de celui de 'cadre'. Pour parfaire le parallélisme, on propose d'appeler 'cadrisme' le système qui correspond au rapport d'encadrement, comme on dit 'capitalisme' à partir de 'capital’” (BIDET, DUMÉNIL, 2007:105)
} 
Esse capitalismo gerencial, ou "capitalismo dos executivos” que aparece justificado em importantes obras de administração de empresas, os anos sessenta, com Alfred $\mathrm{CHANDLER}^{23}$, e setenta, como nas obras de John Kenneth GALBRAITH ${ }^{24}$, vão repercutir no Brasil de modo algo confuso, no início dos anos noventa, coincidindo com obras que já na Europa e nos Estados Unidos, propugnavam por uma terceira forma de gestão (DRUCKER, 2001), que será analisada na seção seguinte deste artigo.

De fato, enquanto na Europa a adesão ao conjunto de valores defendido pelo capitalismo era obtida pela concessão de benefícios por parte do Estado - welfare state - e por parte das empresas ${ }^{25}$ (perspectivas de progressão funcional, quadro de carreira, planos de aposentadoria complementar, melhores condições de trabalho, dentre outros), no Brasil a intervenção estatal se dava não em moldes social-democratas, mas segundo parâmetros burocráticos-autoritários (RAMOS FILHO, 1999) seguindo-se a lógica da incorporação na legislação de um conjunto de direitos a serem assegurados pelo Estado, eis que as empresas durante todo o regime militar não sentiram a necessidade de exercer tal papel. Tinham o Estado e o Exército, ao seu lado para induzir a subordinação de todos aos seus interesses de classe.

Com a redemocratização a necessidade de legitimação é retomada e nesse contexto se deve compreender a extensa inclusão de direitos sociais do trabalho no corpo constitucional de 1988 (necessidade de induzir a adesão de todos ao conjunto de valores consagrados pelo Estado Capitalista de Direito) e o surgimento de alguns estudos da chamada ciência da administração de empresas, ramo do saber científico de características normativas ${ }^{26}$, identificados com esse segundo espírito do capitalismo,

\footnotetext{
${ }^{23}$ Em sua obra de 1959, intitulada "ensaios para uma teoria histórica da grande empresa” o autor desenvolve o conceito segundo o qual os executivos seriam a "mão visível do mercado", corrigindo distorções, e influindo sobre a realidade (CHANDLER, 1998), inaugurando de certa forma a literatura normativa sobre gestão empresarial que caraterizará o período subsequente.

24 “Os seus principais livros, na opinião do próprio autor, foram os que formam a trilogia A sociedade afluente, de 1958, O novo estado industrial, de 1967, e A economia e o objetivo público, de 1973. Nesse último, desenvolveu um tema de grande relevância até hoje, em especial para o nosso país: a profunda interpenetração entre as estruturas tecnoburocráticas do setor privado e do setor público. Galbraith cunhou uma expressão para caracterizar esse fenômeno: "simbiose burocrática". A tecnoestrutura das grandes empresas procura influenciar sistematicamente as políticas públicas, provendo os técnicos e nomeando políticos que tomarão as decisões relevantes para o desenvolvimento das suas atividades privadas. Com a "simbiose burocrática" forma-se um quadro de crescente interação entre grupos privados e funcionários governamentais que acaba contaminando as políticas de governo e colocando-as a serviço de interesses especiais e particulares. Isso é um fato, um fenômeno da vida tanto das sociedades desenvolvidas como de países em desenvolvimento, como o nosso. Os quadros técnicos se movimentam das grandes empresas para o governo e vice-versa, configurando uma situação de captura das alavancas decisórias governamentais” (SUPLICY, 2002)

25 "El segundo espíritu del capitalismo es indisociable de los dispositivos de gestión de las posibilidades promocionales en las grandes empresas, de la puesta en marcha de la jubilación redistributiva y de la extensión, a un número cada vez mayor de situaciones, de la forma jurídica del contrato de trabajo asalariado, de tal forma que los trabajadores puedan beneficiarse de las ventajas asociadas a esta condición. Sin estos dispositivos, nadie habría podido creer realmente las promesas del segundo espíritu” (BOLTANSKI, CHIAPELLO, 2002:69).

${ }^{26}$ No sentido de que esta ciência propõe normas de como devem ser administradas as empresas (no futuro) com base em hipóteses, e não uma ciência descritiva, entendida como aquela que analisa experiências (passadas, portanto) para, identificando pontos em comum, propor alguns elementos que sejam atemporais e universais.
} 
para implantação nas grandes empresas privadas, e, na maioria das vezes, nas numerosas empresas estatais construídas durante o regime militar ${ }^{27}$.

De toda sorte, já em 1995, ao final do que pode ser considerado como o período de consagração do segundo espírito do capitalismo no Brasil (embora já se vislumbrassem elementos caracterizadores do terceiro espírito do capitalismo se consolidando desde o início da década), ou seja, a partir do governo neoliberal que assumira o poder no Brasil no ano anterior, o quadro internacional quanto à consagração em lei de limites à duração semanal do trabalho subordinado era o seguinte (LEE, McCANN; MESSENGER, 2008:40):

\begin{tabular}{|c|c|c|c|c|}
\hline $\begin{array}{c}1995 \\
\text { (ano base) }\end{array}$ & $\begin{array}{l}35-39 \\
\text { horas }\end{array}$ & 40 horas & 41-46 horas & 48 horas \\
\hline África & & $\begin{array}{l}\text { Benin, Burkina Faso, } \\
\text { Camaroes, Chad, } \\
\text { Congo, Costa do } \\
\text { Marfim, Djibouti, } \\
\text { Gabão, Madagascar, } \\
\text { Mali, Mauritania, } \\
\text { Niger, Senegal, Togo }\end{array}$ & $\begin{array}{c}\text { África do Sul, } \\
\text { Angola, Argelia, } \\
\text { Burundi, Cabo } \\
\text { Verde, Republica } \\
\text { do Congo, Guiné- } \\
\text { Bissau, Namibia, } \\
\text { Ruanda, Tanzânia }\end{array}$ & $\begin{array}{c}\text { Marrocos, } \\
\text { Moçambique, Tunísia }\end{array}$ \\
\hline $\begin{array}{c}\text { Ásia e } \\
\text { Oceania }\end{array}$ & & $\begin{array}{c}\text { China, Japão, } \\
\text { Indonésia, } \\
\text { Nova Zelandia } \\
\end{array}$ & $\begin{array}{c}\text { Coréia, Singapura, } \\
\text { Mongólia, }\end{array}$ & $\begin{array}{l}\text { Camboja, Laos, } \\
\text { Malásia, Vietnan, } \\
\text { Filipinas, Tailândia }\end{array}$ \\
\hline Europa & França & $\begin{array}{l}\text { Áustria, Bélgica, } \\
\text { Finlândia, Itália, } \\
\text { Luxemburg, Holanda, } \\
\text { Noruega, Espanha, } \\
\text { Suécia, Letonia, Rússia }\end{array}$ & $\begin{array}{c}\text { Portugal, Suíça } \\
\text { Bulgária, } \\
\text { Rep. Checa, } \\
\text { Eslovênia }\end{array}$ & \\
\hline Américas & & $\begin{array}{l}\text { Estados Unidos, } \\
\text { Canadá, Equador }\end{array}$ & $\begin{array}{c}\text { Brasil, Belize, } \\
\text { El Salvador, } \\
\text { Honduras, } \\
\text { Venezuela }\end{array}$ & $\begin{array}{l}\text { Argentina, Bahamas } \\
\text { Bolivia, Chile, Colombia, } \\
\text { Costa Rica, Guatemala, } \\
\text { México, Nicarágua, } \\
\text { Panamá, Paraguai, } \\
\text { Peru, Uruguay }\end{array}$ \\
\hline
\end{tabular}

Como demonstrado no quadro acima, em 1995, o Brasil já aparece, ao lado de outros países em desenvolvimento como África do Sul, Coréia, Portugal, República Checa e Singapura no grupo dos países cujas leis estabelecem a carga horária semanal normal abaixo das quarenta e oito horas semanais que haviam caracterizado o primeiro espírito do capitalismo a partir do final da primeira guerra mundial.

Significativo também é o crescimento do número de países que (em relação ao quadro anterior) reduzem a carga horária para quarenta horas semanais ou menos. De fato, se em 1967 o grupo de países desenvolvidos que adotavam o limite das quarenta horas semanais se reduzia a Canadá, Finlândia, França, Nova Zelândia e Estados Unidos, agora, quase trinta anos depois, em 1995, o grupo de países cujas legislações

${ }^{27}$ Muito embora não seja objetivo deste artigo inventariar a bibliografia produzida nesse sentido, registra-se que um livro de Ricardo SEMLER, "Virando a própria mesa", de 1988, pode ser situado como elemento de transição para o terceiro espírito do capitalismo que será analisado no tópico seguinte. 
estabelecem a carga horária semanal normal em quarenta horas passa a contar com Áustria, Bélgica, Canadá, China, Estados Unidos, Equador, Espanha, Finlândia, Holanda, Indonésia, Itália, Japão, Letônia, Luxemburgo, Noruega, Nova Zelândia, Rússia e Suécia, sem contar com a França que passa a praticar a semana de trinta e nove horas e a Alemanha ${ }^{28}$ que, como se sabe, começa a fixar, mediante negociações coletivas de âmbito nacional, cargas horárias inferiores a trinta e oito horas semanais.

Sendo certo que o conteúdo da regulação capitalista sobre o trabalho se alterou no período, do qual a redução da carga horária semanal é apenas um aspecto, e que as formas de gestão seguiram exercendo importante papel de legitimação do sistema, com o fim do modelo alternativo, ou seja, com o fim da URSS, assiste-se a significativas metamorfoses na gestão empresarial, como se analisará no tópico seguinte.

\section{NOVAS FORMAS DE GESTÃO, LEGITIMAÇÃO DO CAPITALISMO E DURAÇÃO DO TRABALHO}

Em grande parte dos países, desenvolvidos ou não, no transcurso das últimas três décadas do século XX, a quantidade de trabalho semanal exigida de cada trabalhador nas relações de produção veio sofrendo alteração, como se viu. Mas as alterações no mundo do trabalho, na produção, foram mais profundas. A própria técnica de gestão do segundo espírito do capitalismo restou alterada.

Inicialmente apenas nos países de capitalismo central, mas no início do século atual, espraiando-se globalmente, esse novo modo de gerenciar os recursos humanos estabeleceu-se e consolidou-se, induzindo lealdades, submissão e subserviência ao espírito capitalista que então se engendrava. Esse novo espírito passou a caracterizar-se, em resumo, por (i) gestão por objetivos, (ii) pela gestão racional e (iii) pela possibilidade de se construir uma carreira nas empresas ${ }^{29}$. Esses três elementos asseguravam legitimidade à gestão, credibilidade ao ideário subjacente e adesão do conjunto da sociedade aos valores por ela representados (progresso individual, meritocracia, ascensão social vertical, dentre outros), em ambiente social no qual seriam asseguradas as necessidades mínimas pelo Estado (providência) em regime de liberdade (em oposição ao sistema "concorrente" que, embora mais igualitário acabaria impondo a igualdade à custa da liberdade, o que não seria desejável segundo tal linha de argumentação).

Com o desaparecimento da concorrência ideológica, ou seja, com o fim dos regimes de socialismo real representados pela União Soviética, de certa forma os capitalistas sentiram-se à vontade para tentar “resgatar os anéis cedidos” anteriormente:

\footnotetext{
${ }^{28}$ Conforme http://www.dw-world.de/dw/article/0,,3645495,00.html?maca=bra-rss-br-all-1030-rdf, acesso em 4 fev. 2009.

${ }^{29}$ A carreira viabilizaria segurança à empresa (formação e esforço) e ao trabalhador (motivação, evolução social e econômica). Os mais jovens ganham menos e trabalham mais. Os mais velhos ganham mais e trabalham menos. Este seria o ciclo vital. A segurança no emprego, entendida como necessidade vital faria parte do contrato de trabalho e seria complementada pelo welfare-state. "En la década de 1990 (...) asistimos a un cuestionamiento de ambas protecciones de forma simultánea (...) La apología del cambio, del riesgo y de la movilidad, substituye de este modo a la valorización de la idea de seguridad [...] "El nuevo modelo propone una 'verdadera autonomía (...) basada en el conocimiento de uno mismo y en un pleno desarrollo personal, y no una falsa autonomía, enmarcada por el recorrido de las carreras, las definiciones de las funciones y los sistemas de sanciones-recompensa." (BOLTANSKI, CHIAPELLO, 2002:145).
} 
desde setenta anos antes, quando do início do intervencionismo estatal, com a constituição de Weimar, até as concessões a que se viu obrigado em face da crítica social dos anos 60 e 70. Já não se temia a "perda dos dedos”, teríamos chegado ao “fim da história” (FUKUYAMA, 1992), representada pela definitiva vitória - ideológica - do mercado e da democracia liberal sobre os ideais igualitaristas.

No neofordismo característico da virada do século XX para o XXI os postulados sociais-democratas que singularizavam o segundo espírito do capitalismo deixam, progressivamente, de serem valorizados. O desejo de se construir uma carreira, com segurança no emprego é substituído, ideologicamente, pelo desejo de maior autonomia, pelo desenvolvimento pessoal, pelo crescimento institucional, pelo envolvimento laboral projeto a projeto, tentando-se envolver os trabalhadores na expectativa de que o novo modelo de gestão traria mais felicidade e maior retribuição monetária e espiritual.

Obviamente estes novos postulados geravam uma capacidade de mobilização menor $^{30}$ do que a existente no período anterior, eis que se baseavam em hipóteses a serem confirmadas no futuro, mas agora já não mais existia "a alternativa”. Além disso, ainda não se sabia que quando implementadas no bojo de reformas neoliberais, salvo por exceção, essas novas formas de gestão não produziram para os trabalhadores os efeitos prometidos, de modo crescente esse terceiro espírito do capitalismo passa a conviver, disputando hegemonia, com o segundo espírito capitalista que marcou o período anterior.

Muito embora cada fase do capitalismo tenha, desde sempre, alterado as situações concretas de empregados e empregadores e suas respectivas visões de mundo, as profundas alterações descritas ao longo deste tópico, terminaram por transformar cada trabalhador em um concorrente, um competidor, com os demais trabalhadores. Assim, ao aceitar as "regras do jogo" da competição individual, no interesse do empregador, se produzir mais, se for mais criativo, mais eficiente, termina por colocar o emprego dos demais em risco, desestruturando o que resta de laços de solidariedade intraclasse dominada.

No período precedente, desde o pacto fordista até a implantação do segundo espírito do capitalismo, desenvolvem-se mecanismos de gestão baseados no planejamento por objetivos baseados em valores como descentralização e meritocracia, atendendo às demandas dos próprios executivos de maior autonomia na atividade e adoção da impessoalidade como critério para promoções. No período subsequente, tal sistema de motivação dos executivos e de sedução dos demais trabalhadores, no sentido de adesão aos valores então defendidos, será estruturado a partir da crítica às hierarquias

\footnotetext{
${ }^{30}$ Registre-se, todavia, que essas novas formas de gestão e os novos desejos de maior autonomia e responsabilidades, de modo ambivalente, possuem alguma capacidade sedutora, já que o aumento de autonomia significa correspectivamente diminuição na subordinação, se não ao nível da realidade, pelo menos ao nível da percepção que o trabalhador tem a respeito de sua realidade. Mas mesmo assim, tal aumento de autonomia e de responsabilidade conquanto possam permitir uma ideia de trabalho mais interessante (em comparação com o trabalho totalmente normatizado do espírito do capitalismo anterior) vêm acompanhados de altos níveis de estresse e, de transtornos psico-sociais, e, não raras vezes, de verdadeiros processos de acosso moral decorrente da frenética necessidade de serem atingidas as metas e as expectativas da empresa e de seus acionistas (ROCHEFORT, 2007:57).
} 
empresariais que, segundo a atual visão, conduziriam à excessiva e indesejável burocratização, em detrimento da lucratividade, nos dois espíritos capitalistas anteriores.

No novo sistema de legitimação capitalista a busca se dá pela flexibilidade e criatividade, empresas esbeltas que trabalham em rede, organizadas em equipes orientadas para a satisfação dos clientes e dos acionistas que haverá de ser alcançada por intermédio da mobilização geral dos trabalhadores, seja através da motivação proveniente de seus líderes, seja através da precarização das relações de trabalho ${ }^{31}$.

De fato, a precarização se constitui em estratégia organizacional cujo objetivo é, sobretudo, político no sentido de que visa um incremento na dominação, por intermédio de dois novos métodos de organização do trabalho, ambos voltados para o aumento da produtividade e da lucratividade.

O primeiro é a qualidade total acompanhada de seus sistemas internacionais de certificação e da correlata alteração na modulação da estipulação salarial (pagamento por resultados, por produtividade, dentre outras formas).

O segundo é a avaliação individualizada das performances que em síntese permite a substituição de empregados mais experientes e competentes por jovens recém saídos das escolas técnicas ou das universidades, que não detém o conhecimento geral da produção e, em consequência, são mais facilmente controláveis ${ }^{32}$. As competências e habilidades que cada trabalhador consiga demonstrar nesta avaliação individualizada passam a ser mais importantes que os diplomas universitários, surgindo o conceito de empregabilidade ${ }^{33}$ como atributo pessoal, a ser individualmente buscado, seja por trabalhadores menos qualificados, seja por aqueles com maiores responsabilidades na estrutura funcional das empresas.

A empresa mantém um núcleo estratégico de trabalhadores considerados como essenciais e sub-contrata, terceiriza, boa parte das tarefas. A busca, então, é pelos

\footnotetext{
${ }^{31}$ A globalização da economia e as transformações nos sistemas produtivos alteraram profundamente as relações no espaço da produção, neste período. Estas relações são de dois tipos: as relações de produção, contratualmente estabelecidas entre o capital e o trabalho no marco da regulação estatal (e que constituem no seu conjunto a relação salarial), e as relações na produção que governam o trabalho concreto realizado pelos empregados durante o dia de trabalho, relações entre trabalhadores, destes com supervisores, com gestores, segundo suas normas e regulamentos - a "cultura da empresa". Estes dois tipos de relações, sendo indissociáveis, têm lógicas diferentes e em cada um deles recai de forma diferente o impacto das transformações recentes. Assim, a flexibilização das relações de produção significa invariavelmente a precarização da relação salarial, enquanto a flexibilização nas relações de produção pode significar maior autonomia do processo de trabalho. De toda sorte, as mudanças que o capitalismo mundial continua a experimentar afetam o relacionamento entre as duas categorias acima.

32 "Pour les mettre en place, il faut se débarrasser de la conception traditionnelle de la qualité que est indissociable de la compétence et de l'expérience de métier. Le gens de métier seront donc 'mis au placard' pour neutraliser leur pouvoir critique et remplaces par des gestionnaires sans connaissances techniques, jeunes e malléables, de niveaux bac +2, censés contrôler chez les sous-traitants une qualité ... dont ils ne connaissent pourtant pas les ressorts techniques” (DEJOURS, 2006:60).

33 "Ainsi, surgit e se développe la notion de compétence en tant qu'outil de GRH. Le concept de compétence apparaît comme une combinaison dynamique et complexe de savoirs (connaissances théoriques) de savoir-faire (connaissances pratiques) et de savoir-être (comportements) concentrés dans une action et adaptés aux exigences d'une situation. C'est la possibilité pour un sujet de mobiliser ce qu'il sait et sait faire pour agir dans un contexte donné. De plus, les compétences professionnelles propres d'un individu doivent être transférables dans divers contextes d'emploi” (GUERFEL-HENDA, 2007:146)
} 
trabalhadores mais competentes, flexíveis, criativos e autônomos, gerenciados por um coordenador, não por um chefe, como nos dois espíritos do capitalismo anteriores. Esse novo líder é o manager, que é auxiliado por coachs ou team leaders ${ }^{34}$ e por experts ${ }^{35}$.

O sistema "taylorista" 36 que no fordismo concebia a empresa baseada em estratificação de tarefas, em trabalhadores com especializações rígidas, hierarquizações, em atividades repetitivas e sincronizadas em um tempo controlado para a aceleração da produção e a redução de custos, na busca de maior eficiência, passa a conviver às vezes na mesma empresa - com o que foi chamado de toyotismo ${ }^{37}$ ou de pós-fordismo. Exatamente pela ocorrência da simultaneidade entre os dois métodos de gestão é que se prefere a estas duas expressões, outra: a expressão neo-fordismo, pois as formas tradicionais de gestão não são substituídas por outras, mais modernas, e sim, passam a coexistir.

A estandartização dos processos e sua formalização que caracterizavam o segundo espírito do capitalismo (mas que tinham o inconveniente de possibilitar a existência de um contra-poder sindical nos ritmos da produção) levaram as empresas

34 “Le team work ou travail en groupe constitue le cœur du système dans l'organisation du travail. Il repose sur la responsabilité collective du groupe, la polyvalence des membres du groupe, l'invention du team leader [...] Le team leader nommé parfois moniteur, chef de groupe, responsable d'unité est un collègue, choisi par le groupe ou l'encadrement, qui assure l'interface avec le reste de l'usine ou du service, sans avoir un pouvoir hiérarchique sur ses pairs. Il répartit les tâches, assure le suivi de production et de la qualité, gère les arbitrages entre différents indicateurs de performance affichés dans l'atelier [...] Il existe également des tableaux d'indicateurs communs à différents groupes d'un même process. ”(ROCHEFORT, 2007:56-57).

${ }^{35}$ A visão dos líderes possui "las mismas virtudes que el espíritu del capitalismo, porque garantiza la adhesión de los trabajadores sin tener que recurrir a la fuerza y otorga un sentido al trabajo de cada cual." O termo executivo cai em desgraça, vinculado a burocracia, substituido por manager, designando "todos aquellos (con) gran capacidad para la animación de un equipo y el manejo de las personas, en contraposición con los ingenieros, más centrados en la técnica”, preparados para as incertezas e para a complexidade dos tempos atuais. "Extraen la autoridad que hace de ellos unos 'líderes' de sus cualidades personales y no de una posición estatutaria. (...) Los managers son intuitivos, humanistas, inspirados, visionarios, generalistas y creativos." Existem ainda os coachs - que desenvolvem os potenciais do pessoal da organização - e os experts - que cuidam de saberes muito especializados e imprescindíveis (BOLTANSKI, CHIAPELLO, 2002:125).

${ }^{36} \mathrm{O}$ taylorismo, engendrado no primeiro, mas desenvolvido ao extremo durante a hegemonia do segundo espírito do capitalismo com o planejamento por objetivos (quando o intervencionismo estatal também hegemonizava), tinha por objetivo declarado controlar os obreiros. A direção por objetivos visava enquadrar os executivos, nos mais diversos níveis hierárquicos, às metas fixadas pelos detentores dos meios de produção.

37 "Esse modelo foi aperfeiçoado pelos engenheiros da Toyota durante vinte anos após sua primeira introdução limitada, em 1948”. Segundo este autor, o toyotismo “(...) surgiu como uma possível resposta para superar essa rigidez - típica do sistema taylorista/fordista -. Foi praticado e teorizado de duas formas diferentes: primeiro, como especialização flexível, na formulação de Piore e Sabel, com base na experiência das regiões industriais do norte da Itália, quando 'a produção adapta-se à transformação continua sem pretender controlá-la' em um padrão de arte industrial ou produção personalizada. Práticas similares foram observadas por pesquisadores em empresas de serviços avançados, como as do setor bancário. No entanto, a prática do gerenciamento industrial nas décadas de 1980 e 1990 introduziu outra forma de flexibilidade: a flexibilidade dinâmica, na formulação de Coriat, ou a produção flexível em grande volume, na fórmula proposta por Cohen e Zysman, também demonstrada por Baran para caracterizar a transformação do setor de seguros. (...) As novas tecnologias permitem a transformação das linhas de montagem típicas da grande empresa em unidades de produção de fácil programação que podem atender às variações do mercado (flexibilidade de produto) e das transformações tecnológicas (flexibilidade do processo)” (CASTELLS, 2007:212-215). 
a uma estruturação burocrática e hierarquizada na qual nada era deixado de lado ou ao acaso. Em substituição a tal visão mecânica que presidia a organização funcional e burocrática, a doutrina normativa que instaura o terceiro espírito do capitalismo propõe uma visão adhocrática (governança ad hoc dos processus) que integre o aleatório e a incerteza. A ordem preestabelecida é substituída por uma ordem submetida às perturbações internas e externas prováveis, na qual àquela divisão vertical do trabalho se superpõem o trabalho em equipe e a hipervalorização da polivalência como atributos individuais da empregabilidade e da desejada “organização processual”. Em resumo, a gestão por resultados ou por objetivos é substituída pelo gerenciamento por projetos que se inscrevem dentro da lógica da satisfação do cliente subordinada a uma lógica de satisfação do acionista, do dono do capital ${ }^{38}$.

O referencial de competência de cada posto de trabalho passa a ser mediatizado pela sua contribuição à resposta à expectativa dos clientes ${ }^{39}$ e dos acionistas, dentro de um processo de criação de valor. Tal competência, como gesto mental, se inscreve, muito mais como uma perspectiva organizacional processual do que funcional. Ambas são modelos de organização, embora cada uma induza atitudes mentais e comportamentos diferentes, pois a primeira insiste sobre os processos produtivos enquanto que a segunda sobre as funções e órgãos dentro da empresa, compondo um novo sistema de produção, também denominado como "acumulação flexível ${ }^{40}$, caracterizado pela produção enxuta (lean production). Este novo sistema baseado na mecanização, na informatização e na multifuncionalidade da mão-de-obra, no bojo da reestruturação produtiva, teve efeitos no mercado de trabalho também no Brasil ${ }^{41}$.

38 “Il s'agit de 'désautocentrer' les actions individuelles (effet de la bureaucratie) pour les auto-eco-recentrer en une action collective destinée à répondre au mieux aux attentes des actionnaires en répondant au mieux à celles des clients. A cet effet les postes de travail ont été revisités et réécrits en termes de signes de compétence distribués en niveaux selon les domaines d'activité requis par le poste, ce qui permet d'évaluer la manière dont le titulaire du post répond, à son poste, aux attentes des clients et au-delà des actionnaires" (BRICE, MARCQ, 2007:135)

${ }^{39}$ Para os efeitos aqui pretendidos, retenha-se que a corporate governance que, com o neo-fordismo vem caracterizar o terceiro espírito do capitalismo visava controlar apenas os altos dirigentes, não mais com base em sanções ou recompensas, mas com a motivação e implicação das pessoas, em processo de mobilização permanente em uma das variações possíveis do chamado "foco no cliente".

40 "O modelo japonês implantado desenvolve-se sobre algumas premissas, que se complicam se inseridas no contexto de pós-indústria moderna, mas que podem ser reduzidas a algumas características principais: i) a polivalência do trabalhador; (ii) o planejamento da produção pelo método Kanban/Just in time; (iii) o despertar para o 'chão de fábrica', no sentido de se criarem grupos multifuncionais em cada célula de produção; e (iv) o surgimento dos CCQs” (...).Esta plêiade de princípios teria dado azo à criação de um (...) "sistema de inovações tecnológico-organizacionais, (i) com a robótica e a automação microeletrônica aplicada à produção; (ii) com novas modalidades de gestão da produção, tais como os CCQ'S e programas de qualidade total; (iii) com uma série de racionalizações da produção, tais como os processos de downsizing, de enxugamento da estrutura e reengenharias empresariais de fusões e aquisições; bem como (iv) com terceirizações e relocalizações industriais ” (KAUFMANN, 2005:60 e segs).

41 "Estruturava-se, ainda que de modo incipiente [nesta época], o processo de reengenharia industrial e organizacional, cujos principais determinantes foram decorrência: (i) Das imposições das empresas transnacionais, que levaram à adoção, por parte de suas subsidiárias no Brasil, de novos padrões organizacionais e tecnológicos, em maior ou menor medida inspirados no toyotismo e nas formas flexíveis de acumulação; (ii) Da necessidade, no âmbito dos capitais e de seus novos mecanismos de concorrência, de as empresas brasileiras prepararem-se para a nova fase, marcada por forte 'competitividade internacional'; (iii) Da necessidade de as empresas nacionais responderem ao avanço do novo sindicalismo e das formas de 
A participação estimulada dos empregados nas decisões inerentes aos processos de produção; a concessão de bônus por produtividade; a aglutinação dos setores de produção e controle de qualidade; a desestratificação dos níveis hierárquicos e decisórios; a maior qualificação dos empregados e o surgimento de uma "nova classe operária"; e, por fim, a terceirização de atividades ditas “secundárias” para o processo de produção, permitiram o "sequestro da subjetividade operária” e a consequente fragmentação da solidariedade desta classe (RAMOS FILHO, 2001).

Embora tais metamorfoses no espírito do capitalismo e no modo de gestão das empresas tenham ocasionado o aumento da pobreza no mundo ${ }^{42}$, não se pode negar que foram eficientes: permitiram a ampliação na taxas de produtividade e de lucratividade das empresas, ainda que tais resultados tenham sido obtidos à custa de milhares de empregos.

Evidentemente, no novo contexto trazido pelas novas formas de gestão empresarial questão do número de horas máximo a ser exigido de cada trabalhador, em decorrência de um contrato de emprego, passa a ter sua importância minimizada. A perspectiva segundo qual o estabelecimento de uma jornada normal, de uma carga horária semanal normal de trabalho, seria o resultado de uma luta secular ${ }^{43}$ e continuada, neste novo ambiente, fortemente impactado pelo ideário neoliberal, é substituído por preocupações mais urgentes, dentre as quais a própria manutenção dos empregos.

Não obstante, segundo demonstram estudos recentes, a quantidade de horas prestadas em contrapartida a contratos de emprego, vem caindo em todo o mundo:

\begin{tabular}{|c|c|c|c|c|}
\hline $\begin{array}{c}2005 \\
\text { (ano base) }\end{array}$ & $\begin{array}{l}35-39 \\
\text { horas }\end{array}$ & 40 horas & 41-46 horas & 48 horas \\
\hline África & Chad & $\begin{array}{l}\text { Argelia, Benin, Burkina } \\
\text { Faso, Camarões, Congo, } \\
\text { Costa do Marfim, Djibouti, } \\
\text { Gabão, Madagascar, } \\
\text { Mali, Mauritania, Niger, } \\
\text { Ruanda, Senegal, Togo }\end{array}$ & $\begin{array}{l}\text { Angola, Burundi, } \\
\text { Cabo Verde, Rep. do } \\
\text { Congo, Guiné-Bissau, } \\
\text { Marrocos, Namibia, } \\
\text { África do Sul, } \\
\text { Tanzânia }\end{array}$ & $\begin{array}{c}\text { Moçambique, } \\
\text { Tunísia }\end{array}$ \\
\hline
\end{tabular}

confronto e de rebeldia dos trabalhadores que procuravam estruturar-se mais fortemente nos locais de trabalho, desde as históricas greves do ABC paulista, nos pós-78 e também em São Paulo, onde era significativa a experiência de organização de base nas empresas” (ANTUNES, 2006:18)

${ }^{42}$ Em relatório divulgado em 16.10.2008 com o título de Income Inequalities in the Age of Financial Globalization a OIT concluiu que a globalização financeira tem sido um "importante propulsor da desigualdade de renda" e "não tem contribuído para o fortalecimento da produtividade global e do aumento de emprego". Segundo o mesmo relatório havia a expectativa de que a globalização financeira, "causada pela desregulamentação do fluxo de capital internacional", viesse a estimular o crescimento econômico e trazer benefícios concretos às camadas mais pobres - como aumento de renda e a diminuição nas restrições a crédito. Mas a globalização não apenas "falhou em contribuir no desenvolvimento da produtividade global e na criação de empregos" como também "intensificou a instabilidade econômica", conforme sitio acessado em 2.11.2008, http://diap.ps5.com.br/content,0,1,83667,0,0.html . O relatório confirma dados anteriores divulgados pela própria OIT sobre a desigualdade decorrente da globalização neoliberal trazidos por Boaventura de Sousa Santos: "Segundo a Organização Internacional do Trabalho (OIT), no ano 2000 havia no mundo 160 milhões de desempregados, dos quais 50 milhões nos países desenvolvidos. Além disso, 500 milhões de trabalhadores dispunham de um rendimento inferior a um dólar por dia” (SOUSA SANTOS, COSTA, 2005).

43 “ $L$ 'établissement d'une journée de travail normal est le résultat d'une lutte de plusieurs siècles entre le capitaliste et le travailleur” (MARX, Le capital:355). 


\begin{tabular}{|c|c|c|c|c|}
\hline $\begin{array}{c}\text { Ásia e } \\
\text { Oceania }\end{array}$ & & $\begin{array}{c}\text { China, Japão, } \\
\text { Indonésia, Coréia, } \\
\text { Mongólia, Nova Zelândia }\end{array}$ & Singapura & $\begin{array}{c}\text { Camboja, Laos, } \\
\text { Malásia, Vietnan, } \\
\text { Filipinas, } \\
\text { Tailândia } \\
\end{array}$ \\
\hline Europa & $\begin{array}{l}\text { Bélgica, } \\
\text { França }\end{array}$ & $\begin{array}{l}\text { Áustria, Finlândia, } \\
\text { Itália, Luxemburg, } \\
\text { Holanda, Noruega, } \\
\text { Portugal, Espanha, } \\
\text { Suécia, Bulgária, Rep. } \\
\text { Checa, Estônia, Letônia, } \\
\text { Lituânia, Romênia, Rússia, } \\
\text { Eslováquia, Eslovênia }\end{array}$ & & \\
\hline Américas & & $\begin{array}{c}\text { Estados Unidos, Canadá, } \\
\text { Bahamas, Equador }\end{array}$ & $\begin{array}{c}\text { Brasil, Cuba, } \\
\text { República } \\
\text { Dominicana, Belize, } \\
\text { Chile, El Salvador, } \\
\text { Honduras, } \\
\text { Venezuela }\end{array}$ & $\begin{array}{c}\text { Haiti, Peru, } \\
\text { Argentina, } \\
\text { Bolivia, } \\
\text { Colombia, Costa } \\
\text { Rica, Guatemala, } \\
\text { México, } \\
\text { Nicarágua, } \\
\text { Panamá, } \\
\text { Paraguai, } \\
\text { Uruguay } \\
\end{array}$ \\
\hline
\end{tabular}

As reflexões acima permitem que se passe, a seguir, para o derradeiro tópico deste artigo, no qual se buscará, à guisa de conclusão, estabelecer algumas premissas para a discussão racional sobre o tema na contemporaneidade brasileira.

\section{CONSIDERAÇÕES FINAIS}

O relato da luta pela regulação da duração do trabalho no nosso país permite enunciar a primeira premissa para a discussão racional sobre o tema: a resistência ideológica dos empresários à redução da carga horária semanal, por previsível, não deve impedir ou dificultar a discussão da matéria em termos racionais.

Embora natural e previsível, a resistência empresarial à regulação dos tempos de trabalho não significa que o patronato brasileiro desconsidere o papel do direito do trabalho como instrumento de pacificação social ou à percepção do caráter ambivalente do direito do trabalho. Esta é a razão pela qual nem o mais radical dos empresários e nem o mais dogmático dos liberais, defendem o fim do direito do trabalho: quando aludem a "desregulação" ou a "desregulamentação" na verdade estão a se referir a uma "nova regulação”, menos protetiva dos empregados, mais precária; nunca, uma revogação pura e simples das leis trabalhistas, pois é o direito do trabalho o único ramo do direito que permite a subordinação de um contratante a outro, ou seja, sem o direito do trabalho não haveria sustentação jurídica para a subordinação na relação de emprego, para o poder diretivo do empregador em todos os seus aspectos, inclusive para seu poder disciplinar.

O nível de precariedade ou de proteção vai depender das relações sociais, obviamente. Tal constatação vai nos permitir, então, enunciar a segunda premissa para a discussão da duração do trabalho: o Direito do Trabalho, organizando as relações entre as classes sociais e que experimentou seu desenvolvimento propriamente dito, após o final da segunda grande guerra, ocupando lugar de destaque no sistema de 
legitimação do modo de produção atual, materializa em cada momento histórico, uma correlação de forças que se estabelece na sociedade.

Esse direito do trabalho, decorrente de correlação de forças, se desenvolveu chegando ao final do século XX com significativas metamorfoses, não apenas em seu papel de legitimador do capitalismo, mas, é fato que nos últimos anos do século passado, como demonstram os gráficos acima lembrados, todos os países da atual União Européia promovem reduções legais das cargas horárias normais para quarenta horas semanais consolidando o Estado de bem-estar social naquele continente. No continente africano, o mais pobre, menos desenvolvido e menos industrializado, da mesma forma, quase metade dos países adota carga horária semanal de quarenta horas ou menos. No Oriente Médio e na Ásia, considerados em conjunto, é significativo o número de países que adota limites menores que os praticados no Brasil: cerca de um terço dos países do Oriente Médio pratica carga horária de quarenta horas semanais e na Ásia quase 40\% estabelecem esta carga horária semanal em suas legislações (EVAIN, 2008: gráfico 4). Com muito maior grau de industrialização, a América latina apresenta índices menos protetivos dos trabalhadores: observa-se que apenas o Equador estabelece carga horária de quarenta horas semanais em sua legislação. Entre os demais países, aproximadamente metade dos países estabelece carga horária semanal de até quarenta e cinco horas, nesta franja estatística incluída o Brasil, e metade ainda fixa o limite normal em até quarenta e oito horas semanais.

Esses elementos estatísticos permitem estabelecer a terceira premissa para a discussão da duração do trabalho: a regulamentação da duração do trabalho que se inscreve dentro do sistema de justificação e de legitimação do capitalismo, não guarda relação empírica com o nível de industrialização ou desenvolvimento econômico $e$ social dos países.

Efetivamente, inclusive tendo em vista a globalização com seus diferenciados níveis de desenvolvimento econômico e de industrialização, a distribuição regional de países que adotam a semana de quarenta horas como visto nos parágrafos anteriores não pode ser explicada com base em fatores econômicos, de níveis de industrialização ou de produtividade. A explicação, obviamente, é política. Não no sentido da "vontade política" de seus dirigentes, mas no sentido de que decorrem das relações entre as classes sociais, relações tais que sendo econômicas não deixam de serem também políticas, já que as legislações dos países asseguram maiores ou menores cargas horárias como materializações históricas e concretas de relações que se estabelecem em cada sociedade, entre o empresariado e a classe trabalhadora.

O quadro 3, que sintetiza quais países praticavam em 2005 cargas horárias iguais ou inferiores a quarenta horas demonstra que países latino-americanos dirigidos no início do século XXI por governos menos influenciados pela ideologia neoliberal, em comparação aos governos dos antecessores dos atuais mandatários, não lograram reduzir as jornadas laborais depois de sua chegada ao poder ${ }^{44}$. Do mesmo modo,

44 Referência a KIRCHNER na Argentina, TABARÉ VÁSQUEZ no Uruguai, LUGO no Paraguai, BACHELET no Chile, LULA DA SILVA no Brasil, dentre outros. No Equador, a redução da carga horária para quarenta horas semanais é anterior à chegada de CORREA ao poder. 
verifica-se que em países dirigidos por governos mais a esquerda ${ }^{45}$, que passaram por recentes processos constitucionais, foram mantidas as cargas horárias semanais nos níveis anteriores: a Constituição Bolivariana da Venezuela, muito embora proclame que se buscará sua progressiva redução, estabelece a duração do trabalho diário em oito horas e a carga horária em quarenta e quatro horas semanais ${ }^{46}$; também a constituição da República da Bolívia referendada no início de 2009 com forte resistência de setores conservadores da sociedade boliviana, no campo laboral se restringe a dizer que o trabalho será tutelado pela lei ordinária, sem fixar, na constituição a duração do trabalho ${ }^{47}$.

Tais elementos de análise permitem enunciar a quarta premissa para a discussão a respeito da duração da carga horária semanal: a regulação estatal em geral e o direito do trabalho em particular não refletem mecanicamente os interesses de classe dos ocupantes do poder (como pretendia certo marxismo muito em moda nos anos setenta e oitenta no subcontinente americano), apenas materializam o estágio em que se encontram as relações entre as classes sociais.

Todavia, mesmo sem representar mecanicamente "os interesses da classe dominante” o Estado continua a desempenhar importante papel no sistema de legitimação inerente ao modo de produção capitalista. Em sua primeira entrevista coletiva depois da posse o presidente dos EUA, Barack Obama, afirmou que o "governo federal é a única entidade capaz de oferecer recursos para reativar a economia do país, que enfrenta sua maior crise desde a Grande Depressão"

A gravidade de tal afirmação, todavia, ainda não foi suficientemente assimilada por parte do empresariado brasileiro e de seus intelectuais mais adstritos aos dogmas da ideologia neoliberal.

45 Referência a MORALES na Bolívia, CHAVES, na Venezuela. Na lista poderiam ser incluídos ORTEGA na Nicarágua, e mesmo a CASTRO em Cuba, apesar da revolução socialista naquele pais haver completado meio século.

${ }^{46}$ CONSTITUIÇÃO BOLIVARIANA DE VENEZUELA. Art. 90: "La jornada de trabajo diurna no excederá de ocho horas diarias ni de cuarenta y cuatro horas semanales. En los casos en que la ley lo permita, la jornada de trabajo nocturna no excederá de siete horas diarias ni de treinta y cinco semanales. Ningún patrono o patrona podrá obligar a los trabajadores o trabajadoras a laborar horas extraordinarias. Se propenderá a la progresiva disminución de la jornada de trabajo dentro del interés social y del ámbito que se determine y se dispondrá lo conveniente para la mejor utilización del tiempo libre en beneficio del desarrollo físico, espiritual y cultural de los trabajadores y trabajadoras".

${ }^{47}$ CONSTITUIÇÃO DA REPÚBLICA DA BOLÍVIA. Art. 157: "I. El trabajo y el capital gozan de la protección del Estado. La ley regulará sus relaciones estableciendo normas sobre contratos individuales y colectivos, salario mínimo, jornada máxima, trabajo de mujeres y menores, descansos semanales y anuales remunerados, feriados, aguinaldos, primas u otros sistemas de participación en las utilidades de la empresa, indemnización por tiempo de servicios, desahucios, formación profesional y otros beneficios sociales y de protección a los trabajadores. II. Corresponde al Estado crear condiciones que garanticen para todos posibilidades de ocupación laboral, estabilidad en el trabajo y remuneración justa”. Já a Ley General del Trabajo, em seu artigo 46, estabelece que "La jornada efectiva de trabajo no excederá de 8 horas por día y de 48 por semana. La jornada de trabajo nocturno no excederá de 7 horas entendiéndose por trabajo nocturno el que se practica entre horas veinte y seis de la mañana. Se exceptúa de esta disposición el trabajo de las empresas periodísticas, que están sometidas a reglamentación especial. La jornada de mujeres no excederá de 40 horas semanales diurnas”.

${ }^{48} \mathrm{http}$ //portal.rpc.com.br/gazetadopovo/mundo/conteudo.phtml?tl=1\&id=856162\&tit=Apenas-o-governopode-salvar-a-economia-diz-Obama, acesso em 10 fev. 2009 
A forte intervenção estatal, promovida pelos governos dos países mais desenvolvidos, para salvar as empresas da bancarrota na grave crise econômica de 2008, por um lado, comprometeu todos os esforços desenvolvidos no âmbito da OMC para constituição do livre comércio, pois entre seus postulados se encontra a reprovação peremptória de todas as formas de privilégio às empresas nacionais, inclusive esta da concessão de vultosos empréstimos com juros subsidiados e as campanhas governamentais sugerindo a opção preferencial por produtos nacionais.

Por outro lado, tais intervenções estatais novamente demonstraram que a hipótese da mão invisível do mercado se mostrou inconsistente. De certa maneira, não seria exagerado afirmar-se que a intervenção estatal em 2008 teve para os neoliberais o mesmo efeito que a queda do muro de Berlin teve para os stalinistas em 1989.

Seja como for e como se viu na introdução a este artigo, a retomada do papel do Estado na economia em geral, e no campo das relações de trabalho em particular, com a redução da carta horária semanal, pela via legislativa ou da reforma constitucional, está longe de ser consensual.

Existem divergências tanto no campo empresarial, quanto no campo dos trabalhadores. Ao contrário do que defende o representante dos industriais paranaenses (FIEP), a poderosa FIESP se mostra favorável à redução de jornada de trabalho, mas com redução de salário, como alternativa ao desemprego sustenta ser importante "acelerar o entendimento" entre sindicatos filiados à FORÇA SINDICAL (FS) e sindicatos patronais no sentido da redução da carga horária semanal, medida que não conta com a simpatia da Central Única dos Trabalhadores (CUT), que não admite a redução salarial. O presidente desta entidade paulista, Paulo Skaf, defende que a redução da jornada com redução na remuneração, via acordos coletivos, seria uma alternativa a ser considerada e que isso seria feito "com CUT ou sem CUT". Na avaliação de Skaf, seria preciso "coragem para quebrar paradigmas" no atual cenário em benefício de todos, muito embora a entidade que dirige seja contra a redução da duração do trabalho por força de $\operatorname{lei}^{49}$.

De fato, também no campo dos trabalhadores não há consenso. A CUT além de se opor de modo firme à redução de jornada com redução de salários, também rejeita um eventual "acordo genérico", que possibilitasse a flexibilização dos direitos dos trabalhadores em todos os setores da economia. Segundo seu Presidente, Artur Henrique, os trabalhadores não devem aceitar "que a única proposta seja a dos trabalhadores pagarem a conta dessa crise”. Já a FORÇA SINDICAL, admite redução da carga horária, com redução de salários, mas reivindica, segundo seu secretáriogeral, João Carlos Gonçalves, contrapartidas por parte dos empregadores, como a estabilidade pelo dobro do período em questão. Por fim, a CGTB (Central Geral dos Trabalhadores do Brasil) e a UGT (União Geral dos Trabalhadores) admitem negociar férias, licença remuneradas, banco de horas e suspensão do contrato de trabalho, como medidas para enfrentamento da crise ${ }^{50}$, confirmando o baixíssimo nível de consenso sobre a questão, mesmo no movimento sindical.

49 http://oglobo.globo.com/economia/mat/2009/01/14/presidente-da-fiesp-paulo-skaf-diz-que-reducao-dejornada-salarios-nao-garante-emprego-684796691.asp

${ }^{50}$ Conforme jornal FOLHA DE SÃO PAULO, de 15.01.2009. 
Do que acima constou, se pode chegar à quinta premissa indispensável para que o debate sobre a redução da carga horária semanal se dê segundo critérios racionais: mesmo com a retomada do papel do Estado em decorrência da crise econômica de 2008, o ideário neoliberal segue não apenas existindo, como também segue disputando hegemonia com o intervencionismo estatal, fato este que não permite que se conclua, com segurança, se o Brasil optará por mais regulação, com nova redução da duração do trabalho, ou se remanescerá prevalente, embora combalido, o conjunto ideológico que propugna pela auto-regulação.

No campo das representações simbólicas mais próximo do empresariado e em algumas manifestações de jornalistas, doutrinadores, políticos, professores universitários, magistrados, advogados empresariais, economistas liberais, entre outros, vislumbra-se a utilização da crise econômica em pelo menos duas direções, distintas embora complementares.

A primeira apropriação utilitarista da existência da crise consiste em tentar buscar ainda algum tipo de sustentação para o ideário neoliberal, mesmo após o contraditório apelo feito pelos mercados aos Estados no sentido de exigirem fortes intervenções públicas para salvar bancos e empresas. Sustentando "não ser o momento para regozijo dos keynesianos" (neste significante englobados todos os que defendem o intervencionismo estatal como mecanismo válido e útil para diminuição das diferenças entre as classes sociais), tais setores invocam a existência da crise real do capitalismo para impedir o debate sobre os graves prejuízos que os profetas da ideologia neoliberal causaram em várias partes do mundo a milhões de pessoas. Assim como no período em que o neoliberalismo era hegemônico buscavam tornar invisíveis os verdadeiros beneficiários das medidas que propunham (RAMOS FILHO, 2001), agora se tenta invisibilizar os responsáveis pela bancarrota de proporções globais, tentando salvar a ideologia desta contradição insanável: a mão invisível do mercado não funcionou mais uma vez e foi necessária a forte intervenção estatal para salvar o capitalismo.

A segunda utilização da crise para finalidades políticas que interessam ao empresariado consiste em renovado ataque aos direitos sociais. Contraditoriamente, mesmo tendo sido constatados os efeitos danosos da liberalização das relações de trabalho em todo o mundo, tentam sacar vantagem da crise propondo, novamente, a precarização das relações de emprego, eufemisticamente denominada como “modernização” ou como “desregulamentação”, propugnando pela instituição de mecanismos que permitam flexibilizar ainda mais o direito do trabalho brasileiro. Em oposição a tal tendência, intelectuais brasileiros comprometidos com os direitos humanos compreendidos em sua complexa indivisibilidade divulgaram no final de janeiro de 2009 manifesto denominado Contra oportunismos e em defesa do Direito Social", no qual se sustenta que "uma crise econômica, vista do ponto de vista estrutural,

${ }^{51}$ Capitaneado pelo Professor Jorge Luiz SOUTO MAIOR, tal documento contou com a adesão inicial de 243 intelectuais vinculados aos direitos humanos e de diversos segmentos sociais, como magistrados do trabalho, procuradores, advogados, professores universitários, doutrinadores, cobrindo amplo espectro social. Ver http://www.viomundo.com.br/apoiamos/contra-quem-usa-a-crise-para-atacar-direitos. 
se concretamente existente, somente pode ser superada por meio de um autêntico pacto social, que envolva os setores da produção, do trabalho e do consumo, gerenciado pelo Estado, e no qual se priorize a construção da justiça social” e que "se estamos diante de uma crise econômica, já estamos vivendo uma crise de natureza social, moral e ética há muito tempo e a solução desta última é, por óbvio, mais urgente". O documento continua afirmando que "há de se reconhecer que a superação de uma crise econômica estrutural requer sacrifícios de cima para baixo e não de baixo para cima. Não se promove uma sociedade, salvando empresas e deixando pessoas à beira da fome. Se há um problema na conjuntura econômica, que atinge a todos indistintamente, e não apenas a uma ou outra empresa, é necessário, então, o sacrifício conjunto, começando pelos próprios empresários e passando por diversos outros setores da sociedade (profissionais liberais, servidores públicos, senadores, deputados, prefeitos, governadores, juízes etc). É impensável que se busque a solução de problemas econômicos estruturais do país com o sacrifício apenas de trabalhadores cujo salário já está entre os mais baixos do mundo". ${ }^{52}$

O debate que agora se estabelece na sociedade e no parlamento com a discussão da PEC 231/95, deve ser feito do modo mais racional possível, embora se reconheça a dificuldade do empresariado brasileiro neste sentido (primeira premissa), já que o direito do trabalho continuará exercendo importante papel no sistema de legitimação do modo de produção, organizando as relações entre as classes sociais (segunda premissa). Considerando que a regulação estatal, pelo menos no que respeita à carga horária legal semanal, não guarda relação nem com o nível de industrialização de cada país (terceira premissa), nem com a posição ideológica dos governantes, simplesmente materializando o estágio em que se encontram as relações entre as classes sociais (quarta premissa) impende reconhecer que neste momento de saída da crise econômica cujo primeiro efeito social é o aumento do desemprego ${ }^{53}$ o tema da redução da duração do trabalho - que racionalmente possibilita uma oferta maior de empregos - pode ser enfrentando tanto pelo viés neoliberal, que embora debilitado segue tendo ferrenhos defensores, quanto pelo viés intervencionista, pela defesa de uma nova regulação, menos tutelar dos interesses dos empresários e mais tuitivo dos interesses dos empregados (quinta premissa). A resultante deste dilema, como se viu, dependerá da correlação de forças entre as classes sociais.

${ }^{52} \mathrm{O}$ manifesto conclui afirmando que "A tão propalada "flexibilização", no fundo, é um eufemismo, ou seja, uma maneira amena de se alcançar a redução dos direitos trabalhistas, que, no Brasil, já deu mostras claras de sua falácia, visto que estando entre nós de desde 1967, quando fora criado o FGTS para acabar com a estabilidade no emprego (passando por: trabalho temporário, 1974; lei de estágio, 1977; vigilância, 1983; terceirização, 1993; banco de horas, 1998; contrato provisório, 1998; trabalho a tempo parcial, 1998; redução da prescrição do trabalho rural, 2000; limitação da natureza salarial de benefícios concedidos ao empregado, 2001; suspensão temporária do contrato de trabalho, 2001; primeiro emprego, 2003), não produziu qualquer resultado satisfatório em termos de melhoria da economia com produção de justiça social, muito pelo contrário”.

${ }^{53}$ Segundo a OIT "a atual crise econômica irá gerar 20 milhões de novos desempregados no mundo até o final de 2009, revertendo anos de avanços na área social e agravando a pobreza e desigualdade. O alerta é da Organização Internacional do Trabalho (OIT) que prevê demissões em massa diante da desaceleração das principais economias do mundo, como Estados Unidos, Europa e Japão", conforme veiculado em: http://www.estadao.com.br/economia/not_eco262943,0.htm 
De todo modo, se faz necessário reconhecer racionalmente a necessidade de o Brasil assegurar aos seus cidadãos as mesmas condições de trabalho já asseguradas até por países que se encontram em menores níveis de industrialização, como medida de combate ao desemprego, pois se contata que entre os que limitam em quarenta horas a carga horária normal semanal encontram-se países industrializados como Áustria, Bélgica, Canadá, China, Coréia, Estados Unidos, Espanha, Finlândia, Holanda, Itália, Japão, Luxemburgo, Noruega, Nova Zelândia, Rússia e Suécia e outros nem tanto, como Indonésia, Argélia, Bulgária, Equador, Estônia, Eslováquia, Eslovênia, Letônia, Lituânia Romênia, e países pobres, alguns dos quais bastante subdesenvolvidos, como Benin, Burkina Faso, Camarões, Congo, Costa Do Marfim, Djibouti, Gabão, Madagascar, Mali, Mauritânia, Níger, Ruanda, Senegal e Togo (LEE; McCANN, MESSENGER, 2008:30-46).

No debate que se avizinha com a tramitação da PEC 231/95 que trata da redução da jornada de trabalho no Congresso Nacional, o Brasil terá que fazer a opção entre participar do conjunto de países acima, ou permanecer ao lado de estados que baseiam suas economias em cargas de trabalho excessivas, com reflexo nos níveis de emprego, como Angola, Burundi, Cabo Verde, Guiné-Bissau, Marrocos, Namíbia, Republica do Congo, Tanzânia e como a maioria dos países latino-americanos.

Utilizando outro parâmetro, se pode constatar que, mesmo considerando que alguns países densamente populosos como Índia e Paquistão não estabeleceram em lei um limite semanal para a duração do trabalho, tomando-se por base apenas os países que já fixaram a duração do trabalho em menos de quarenta horas semanais, se pode concluir que perto de dois terços da humanidade vive em Estados que estabeleceram tal garantia, seja em leis, seja em suas Constituições, seja em contratos coletivos firmados em bases de reconhecimento dos direitos humanos sociais.

A conquista das quarenta horas semanais, aparentemente, não virá do reconhecimento racional por parte das elites no sentido de que nosso país, com o desenvolvimento alcançado, deve garantir os mesmos direitos sociais assegurados pelos demais países desenvolvidos ou em desenvolvimento. Tal conquista também não decorrerá da mera "evolução" das ideias, de formas mais primárias para mais complexas até atingir o "progresso social”, transformado em lei, como poderiam supor liberais-positivistas bem intencionados.

As quarenta horas semanais terão que ser conquistadas na correlação de forças entre os trabalhadores e o patronato, como em todo o mundo, como em todas as épocas, pois o direito nada mais é do que a materialização histórica e concreta da correlação de forças que se estabelece na sociedade; uma materialização de uma relação entre classes sociais, que apesar de terem interesses antagônicos e inconciliáveis, encontram na regulação estatal o estatuto de sua convivência.

\section{BIBLIOGRAFIA}

ANTUNES, Ricardo. A Era da Informatização e a época da informalização. In ANTUNES, Ricardo (org). Riqueza e Miséria do Trabalho no Brasil. São Paulo: Ed. Boitempo, 2006.

BAYLOS, Antônio. Derecho del Trabajo: Modelo para Armar. Madrid: Ed. Trotta, 1991.

BIDET, Jacques et DUMÉNIL, Gérard. Altermarxisme: un autre marxisme pour un autre monde. Paris: Ed. PUF, 2007. 
BOLTANSKI, Luc. y CHIAPELLO, Ève. “El Nuevo Espíritu del capitalismo”. Madri: Ed. Akal, 2002.

BRICE, Hélène et MARCQ, Joël. Une passage difficile vers logique competence: cas Enercop. In: LE ROUX, Serge et MARCQ, Joël. LE TRAVAIL, Formes récentes et nouvelles questions. Dunkerque: L’Harmattan, 2007, pp.125-143).

CAHUC, Pierre et ZYLBERBERG, André. Le Chomage, Fatalité ou Nécessité ? Paris: Ed. Flamarion, 2005.

CASTEL, Robert. As metamorfoses da questão social: uma crônica do salário. Rio de Janeiro: Ed. Vozes, 6. ed., 1998.

CASTELLS, Manoel. A Sociedade em Rede. São Paulo: Ed. Paz e Terra, 2007.

CHANDLER, Alfred. Ensaios para uma teoria histórica da grande empresa. Rio de Janeiro: FGV, 1998.

DAL-ROSSO, Sadi. A Jornada de Trabalho na Sociedade: O castigo de Prometeu. São Paulo: LTr, 1996.

DEJOURS, Chistophe. La flexibilité, ou l'autre nom de la servitude. In : HUSSON, Michel. Travail flexible, salariés jetables. Paris: Ed. La Découverte, 2006, pp. 53-63.

DRUCKER, Peter F. O Melhor de Peter Drucker: o Homem, a Administração e a Sociedade. São Paulo: Ed. Nobel, 2001.

EVAIN, Eléonore. Working conditions laws 2006-2007: A global review; International Labour Office - Genebra: ILO, 2008.

FUKUYAMA, Francis. O fim da história e o último homem. Rio de Janeiro: Ed. Rocco, 1992. GALBRAITH, John Kenneth. O Novo Estado Industrial. São Paulo: Editora Pioneira, 2. ed. 1983.

GUERFEL-HENDA, Sana. Validation des acquis d'expérience: source de développement des compétences et d'innovation au niveau de la gestion des ressources humaines (GRH). In: LE ROUX, Serge et MARCQ, Joël. LE TRAVAIL, Formes récentes et nouvelles questions. Dunkerque: L’Harmattan, 2007, pp.145-164.

KAUFMANN, Marcus de Oliveira. Das práticas anti-sindicais às práticas anti-representativas: sistemas de combate e a tutela das representações coletivas de trabalhadores. São Paulo: LTr, 2005.

LEE, Sangheon; McCANN, Deirdre; MESSENGER, John C. El tiempo de trabajo en el mundo. Tendencias en horas de trabajo, leyes y políticas en una perspectiva global comparativa. Madrid: Ministerio de Trabajo e Inmigración, 2008.

MARX, Karl. Le capital. Paris: Ed. Gallimard, 1963.

MÉDA, Dominique. Les 35 heures dans l'histoire séculaire de la réduction du temps de travail. In BRUNES, Bernard et alli. 35 Heures : Le temps du bilan. Paris: Desclée de Brouwer, 2001, pp. 13-20.

MORAES, Evaristo de. Apontamentos de Direito Operário. 4. ed. São Paulo: LTr, 1998.

MOURA, José Barros. A Convenção Colectiva entre as fontes de Direito de Trabalho. Coimbra, Livraria Almeidina, 1984.

NASCIMENTO, Amauri Mascaro. Curso de Direito do Trabalho. São Paulo: Saraiva Ed, 2008.

OIT - ORGANIZAÇÃO INTERNACIONAL DO TRABALHO. Hours of work. A Word survey of national Law and practice. International Labour Office - Genebra: 1967. 
Working time around the world. Trends in working hours, laws and policies in a global comparative perspective. International Labour Office - Genebra: ILO, 2007.

Working conditions laws 2006-2007: A global review. International Labour Office Genebra: ILO, 2008.

PEREIRA DA SILVA, Josué. Três discursos, uma sentença. Tempo e trabalho em São Paulo - 1906/1932. São Paulo: Annablume/FAPESP, 1996.

RAMOS FILHO, Wilson. O Fim do Poder Normativo da Justiça do Trabalho e a Arbitragem. São Paulo: LTr, 1999.

Direito, economia, democracia e o sequestro da subjetividade dos juslaboralistas. $\overline{R e v i s t a}$ do Tribunal Regional do Trabalho da $9^{a}$ Região. Curitiba, páginas 147 a 166, 2001.

ROCHEFORT, Thierry. Nouveau modèle productif et crise du travail: une approche sociologique en terme de configurations productives conflictuelles. In : LE ROUX, Serge et MARCQ, Joël. LE TRAVAIL, Formes récentes et nouvelles questions. Dunkerque: L'Harmattan, 2007, pp. 43-76.

ROPPO, Enzo. O Contrato. Coimbra: Livraria Almedina, 1988.

SANTANA, Márcio Santos. A virada da Questão Social: a Indústria, o trabalho do menor e a intermediação estatal. Disponível no sítio, http://www.fflch.usp.br/dh/posgraduacao/ economica/spghe/pdfs/Santana_Marcio_Santos_de.pdf, acessado em 08 jan. 09;

SEMLER, Ricardo. Virando a própria mesa. São Paulo: Ed. Best Seller, 1988.

SOUSA SANTOS, Boaventura e COSTA, H. A. Introdução: Para ampliar o cânone do internacionalismo operário. In SOUSA SANTOS, Boaventura (org.). Trabalhar o mundo. Rio de Janeiro: Ed. Civilização Brasileira, 2005.

SUPLICY, Eduardo Matarazo. Sobre o legado de John Kenneth Galbraith. Revista de Economia Política, vol. 26, nº 4, São Paulo: 2006.

WEBER, Max. A ética protestante e o espírito do capitalismo. São Paulo: Companhia das Letras, 2004. 